Prepared in cooperation with the Idaho Department of Water Resources

\title{
Recharge Sources and Residence Times of Groundwater as Determined by Geochemical Tracers in the Mayfield Area, Southwestern Idaho, 2011-12
}

Scientific Investigations Report 2013-5115 



\section{Recharge Sources and Residence Times of Groundwater as Determined by Geochemical Tracers in the Mayfield Area, Southwestern Idaho, 2011-12}

By Candice B. Hopkins

Prepared in cooperation with the Idaho Department of Water Resources

Scientific Investigations Report 2013-5115 


\title{
U.S. Department of the Interior SALLY JEWELL, Secretary
}

\section{U.S. Geological Survey Suzette M. Kimball, Acting Director}

\author{
U.S. Geological Survey, Reston, Virginia: 2013
}

For more information on the USGS - the Federal source for science about the Earth, its natural and living resources, natural hazards, and the environment, visit http://www.usgs.gov or call 1-888-ASK-USGS.

For an overview of USGS information products, including maps, imagery, and publications, visit http://www.usgs.gov/pubprod

To order this and other USGS information products, visit http://store.usgs.gov

Any use of trade, firm, or product names is for descriptive purposes only and does not imply endorsement by the U.S. Government.

Although this information product, for the most part, is in the public domain, it also may contain copyrighted materials as noted in the text. Permission to reproduce copyrighted items must be secured from the copyright owner.

Suggested citation:

Hopkins, C.B., 2013, Recharge sources and residence times of groundwater as determined by geochemical tracers in the Mayfield Area, southwestern Idaho, 2011-12: U.S. Geological Survey Scientific Investigations Report 2013-5115, 36 p., http://pubs.usgs.gov/sir/2013/5115/. 


\section{Contents}

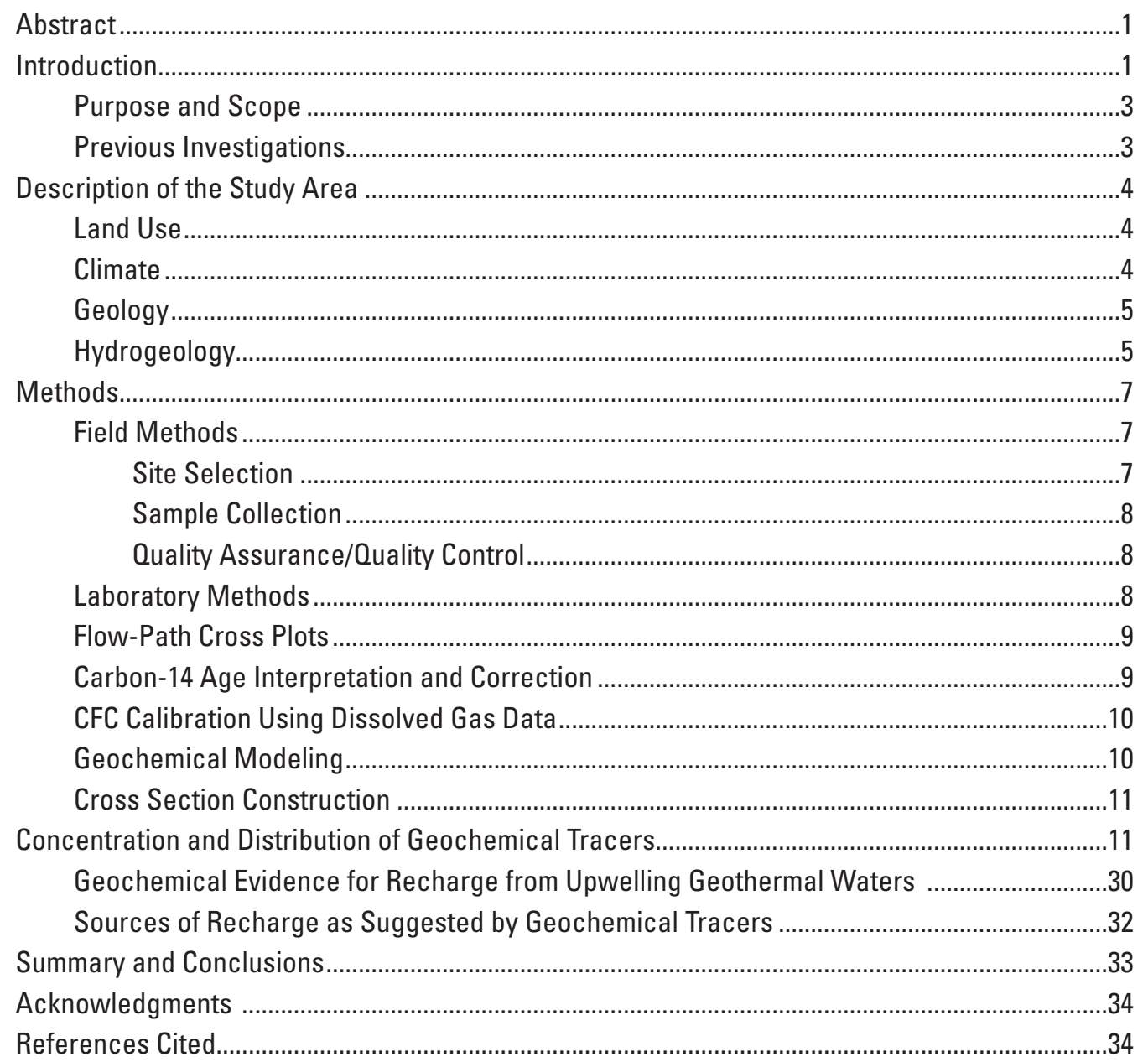




\section{Figures}

1. Map showing Mayfield study area and water-quality sampling locations, southwestern Idaho

2. Graph showing discharge at U.S. Geological Survey streamflow-gaging station Indian Creek near Mayfield, Idaho, July 2010-July 2012

3. Graphs showing major ion concentrations along a relative flow path in water samples collected in wells from the Mayfield area, southwestern Idaho, 2011-12.......13

4. Graph showing nitrate concentration compared with carbon-14 in water samples collected from the Mayfield area, southwestern Idaho, 2011-12 15

5. Graph showing concentrations of arsenic and lithium along a relative flow path in water samples collected from wells from the Mayfield area, southwestern Idaho, 2011-12.

6. Graph showing oxygen and hydrogen isotopes from groundwater and surface water in the Mayfield area, southwestern Idaho, 2011-12, plotted with a global meteoric water line (GMWL) and two local meteoric water lines (LMWLs).....

7. Cross section showing selected wells and percentages of young water in samples collected in the Mayfield area, southwestern Idaho, 2011-12 .25

8. Graph showing $\mathrm{pH}$ and fluoride concentrations in water samples collected from wells in Mayfield area, southwestern Idaho, 2011-12..

9. Ternary diagram showing water samples plotted with Idaho Batholith thermal water, Mayfield area, southwestern Idaho, 2011-12.

\section{Tables}

1. Summary of data from selected weather stations near the Mayfield area, southwestern Idaho, 2011-12.

2. Site location information for wells and surface-water sites sampled in the Mayfield area, southwestern Idaho, 2011-12.

3. Field parameter values for water samples collected in the Mayfield area, southwestern Idaho, 2011-12

4. Major-ion concentrations in water samples collected from the Mayfield area, southwestern Idaho, 2011-12

5. Nutrient concentrations in water samples collected in the Mayfield area, southwestern Idaho, 2011-12

6. Metals and trace-element concentrations for water samples collected in the Mayfield area, southwestern Idaho, 2011-12

7. Isotope data and corrected carbon-14 ages for water samples collected in the Mayfield area, southwestern Idaho, 2011-12

8. Dissolved gas data and estimated recharge temperatures for water samples collected in the Mayfield area, southwestern Idaho, 2011-12.

9. Chlorofluorocarbon results and simulated groundwater recharge dates based on recharge elevation for groundwater samples collected in the Mayfield area, southwestern Idaho, 2011-12

10. Saturation indices of selected water samples from wells in the Mayfield area, southwestern Idaho, 2011-12

11. Geochemical model simulations results using NETPATH, measured carbon-14 and calculated carbon-14 ages, and flow path modeling travel times for groundwater in the Mayfield area, southwestern Idaho, 2011-12.

12. Validity of mixing models using NETPATH, Mayfield area, southwestern Idaho, 2011-12 


\section{Conversion Factors}

Inch/Pound to SI

\begin{tabular}{lll}
\hline \multicolumn{1}{c}{ Multiply } & By & \multicolumn{1}{c}{ To obtain } \\
\hline inch (in.) & Length & \\
foot (ft.) & 2.54 & centimeter $(\mathrm{cm})$ \\
mile (mi) & 0.3048 & meter $(\mathrm{m})$ \\
& 1.609 & kilometer $(\mathrm{km})$ \\
\hline cubic foot per second $\left(\mathrm{ft}^{3} / \mathrm{s}\right)$ & Flow rate & \\
\hline & 0.02832 & cubic meter per second $\left(\mathrm{m}^{3} / \mathrm{s}\right)$ \\
\hline foot per mile $(\mathrm{ft} / \mathrm{mi})$ & Hydraulic gradient & \\
\hline
\end{tabular}

Temperature in degrees Celsius $\left({ }^{\circ} \mathrm{C}\right)$ may be converted to degrees Fahrenheit $\left({ }^{\circ} \mathrm{F}\right)$ as follows:

$$
{ }^{\circ} \mathrm{F}=\left(1.8 \times{ }^{\circ} \mathrm{C}\right)+32
$$

Temperature in degrees Fahrenheit $\left({ }^{\circ} \mathrm{F}\right)$ may be converted to degrees Celsius $\left({ }^{\circ} \mathrm{C}\right)$ as follows:

$$
{ }^{\circ} \mathrm{C}=\left({ }^{\circ} \mathrm{F}-32\right) / 1.8
$$

Specific conductance is given in microsiemens per centimeter at 25 degrees Celsius $(\mu \mathrm{S} / \mathrm{cm}$ at $\left.25^{\circ} \mathrm{C}\right)$.

Concentrations of chemical constituents in water are given either in milligrams per liter (mg/L) or micrograms per liter $(\mu \mathrm{g} / \mathrm{L})$.

Datums

Vertical coordinate information is referenced to the North American Vertical Datum of 1988 (NAVD 88).

Horizontal coordinate information is referenced to the North American Datum of 1983 (NAD 83).

Altitude, as used in this report, refers to distance above the vertical datum.

Abbreviations and Acronyms

CFC chlorofluorocarbon

GMWL Global Meteoric Water Line

IDWR Idaho Department of Water Resources

LMWL Local Meteoric Water Line

NWISWeb USGS National Water Information System website (NWISWeb)

pmc percent modern carbon

RASA Regional Aquifer System Analysis

SRP Snake River Plain

USGS U.S. Geological Survey

VSMOW Vienna Standard Mean Ocean Water 
This page intentionally left blank. 


\title{
Recharge Sources and Residence Times of Groundwater as Determined by Geochemical Tracers in the Mayfield Area, Southwestern Idaho, 2011-12
}

\author{
By Candice B. Hopkins
}

\section{Abstract}

Parties proposing residential development in the area of Mayfield, Idaho are seeking a sustainable groundwater supply. During 2011-12, the U.S. Geological Survey, in cooperation with the Idaho Department of Water Resources, used geochemical tracers in the Mayfield area to evaluate sources of aquifer recharge and differences in groundwater residence time. Fourteen groundwater wells and one surface-water site were sampled for major ion chemistry, metals, stable isotopes, and age tracers; data collected from this study were used to evaluate the sources of groundwater recharge and groundwater residence times in the area.

Major ion chemistry varied along a flow path between deeper wells, suggesting an upgradient source of dilute water, and a downgradient source of more concentrated water with the geochemical signature of the Idaho Batholith. Samples from shallow wells had elevated nutrient concentrations, a more positive oxygen-18 signature, and younger carbon-14 dates than deep wells, suggesting that recharge comes from young precipitation and surface-water infiltration. Samples from deep wells generally had higher concentrations of metals typical of geothermal waters, a more negative oxygen-18 signature, and older carbon-14 values than samples from shallow wells, suggesting that recharge comes from both infiltration of meteoric water and another source. The chemistry of groundwater sampled from deep wells is somewhat similar to the chemistry in geothermal waters, suggesting that geothermal water may be a source of recharge to this aquifer. Results of NETPATH mixing models suggest that geothermal water composes 1-23 percent of water in deep wells. Chlorofluorocarbons were detected in every sample, which indicates that all groundwater samples contain at least a component of young recharge, and that groundwater is derived from multiple recharge sources. Conclusions from this study can be used to further refine conceptual hydrological models of the area.

\section{Introduction}

The population of Ada County, Idaho, has increased from about 112,000 in 1970 to 373,406 in 2007 (Church, 2007). The Community Planning Association of Southwestern Idaho predicts that the population of Ada County will grow to 875,960 by 2040 (Church, 2007). Development ( 8,000 homes) is planned for eastern Ada County and western Elmore County near the Mayfield town site (fig. 1). A sustainable water supply is crucial to the future development of the Mayfield area. That supply could come entirely from Mayfield area groundwater, or from groundwater used in combination with water brought in by pipeline from an outside area. To ensure a sustainable water supply, the Idaho Department of Water Resources (IDWR) is charged with the issuance of water rights, and is conducting studies to determine long-term water supply and possible sources of interference with existing water rights.

Limited information is available on the hydrogeology of the area. Recent efforts by IDWR have included waterlevel monitoring and interpretation. Studies commissioned by developers have assessed potential groundwater availability in the area, but additional questions exist about the sustainability of groundwater. Some of these questions relate to the amount and sources of recharge. A better understanding of recharge can help to constrain conceptual models of the hydrology, and to guide future decision making. This study was conducted by the U.S. Geological Survey (USGS) in cooperation with IDWR. It was initiated to determine the sources of groundwater recharge and groundwater residence times in the Mayfield area by examining geochemical characteristics of groundwater occurring along a flow path, and differences in the geochemistry of groundwater with depth. 


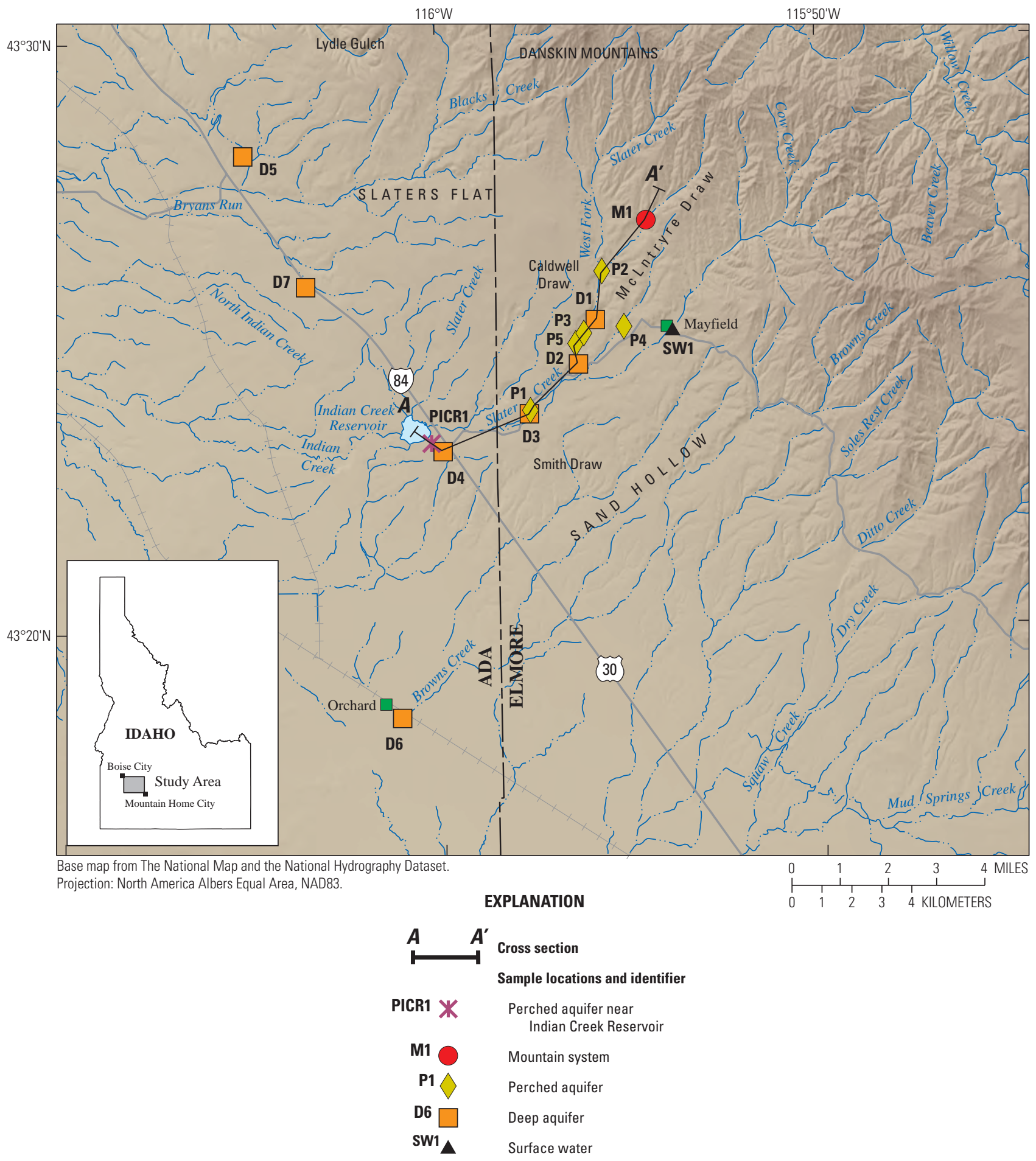

Figure 1. Mayfield study area and water-quality sampling locations, southwestern Idaho. 


\section{Purpose and Scope}

This report identifies sources of recharge and the residence times of groundwater in the Mayfield area of southwestern Idaho (fig. 1) by characterizing isotopic and environmental tracers in groundwater and surface water. It includes brief discussions of environmental tracers, how they are used to better understand hydrogeology, and the waterquality analyses for samples collected from 14 wells and 1 stream during 2011-12.

\section{Previous Investigations}

Several regional studies have examined the groundwater geochemistry of southwestern Idaho, including the Mayfield area. Although most of these studies included little data from the Mayfield area itself, they did provide valuable background information about the water quality of the area.

Wood and Low (1988) presented work done as part of the USGS Snake River Plain (SRP) Regional Aquifer System Analysis (RASA) program. Because the RASA was a regional study, few samples were collected and analyzed in the Mayfield area. The main focus of this work was to identify the chemical reactions between the aquifer matrix and groundwater that control solute concentrations in the SRP aquifer system.

Parliman and Young (1992) described selected well-inventory and water-chemistry data for 718 thermal-water wells and springs in Idaho, including four near the Mayfield area. Analyses included major ions, nutrients, bacteria, trace elements, and oxygen/deuterium.

Neely and Crockett (1998) presented water-quality data collected from 281 wells in the Treasure Valley area (144 wells were less than $250 \mathrm{ft}$ depth; 137 wells were greater than $250 \mathrm{ft}$ depth), including a number of wells near the Mayfield area. The data collected included major ions, nutrients, and trace elements. The study included an evaluation of network design, trend analysis of selected constituents, and scatter plots and trilinear diagrams.

Hutchings and Petrich (2002) sampled 38 wells in the Boise River drainage basin. Only one of the wells sampled for that study is near the Mayfield area. Analytes included major ions and carbon isotopes. Radiocarbon was analyzed in a subset of 28 wells; a carbon-14 correction model based on carbon-13 values was recommended. The youngest waters were located adjacent to the northern foothills, increasing in age towards the western edge of the basin near the Snake River with a corresponding increase in groundwater mineralization.
Reports focusing specifically on the Mayfield study area have been published as interest in the development of the study area has increased. SPF Water Engineering (2007a) conducted a preliminary study to determine the availability and sustainability of groundwater in the vicinity of Mayfield. The study also examined water demand, local geology, drillers' reports, and the possible effects of pumping. Suggested recharge sources were seepage from surface channels, infiltration of precipitation, and underflow from the Danskin Mountains. SPF Water Engineering did not suspect discharge from the shallow aquifers into Indian Creek. Geochemical data collected for the SPF Water Engineering (2007a) study included major ions and nutrients; estimates for evapotranspiration, stream seepage, and precipitation also were included in this study.

In a follow up study, SPF Water Engineering (2007b) examined rising groundwater levels in a proposed development to the south of the Mayfield area. The study examined previously available water-quality data from the Idaho Statewide Ground Water Quality Monitoring Program; the authors suggested the area had "good" water quality. Water temperature and arsenic concentrations were noted to increase with depth. The SPF Water Engineering (2007b) report also contains information on precipitation and evaporation, infiltration estimates, and a water budget. In addition, geological information available from drillers' logs was described.

Welhan (2012) evaluated previously existing geochemical and hydrogeological data in the Mayfield study area. Possible recharge was determined to be from infiltration of surface water, precipitation or meteoric recharge from local drainage basins, and upwelling of deep geothermal water. Recharge estimates based on pumping tests suggested that previous estimates of recharge were too high. The Welhan (2012) study recommended that additional geochemical and groundwater temperature data be collected from the Mayfield study area.

IDWR has published numerous technical memos that describe the hydrology and geology of the Mayfield area. In addition, several groundwater studies have been conducted near the study area due to its proximity to areas of increased concern over groundwater supply. The Mayfield study area overlaps the Mountain Home Ground Water Management Area. Additionally, several proposed developments in the study area are within $5 \mathrm{mi}$ of the northern boundary of the Cinder Cone Butte Critical Groundwater Area. IDWR has designated these areas as areas of groundwater concern because they seem to have, or may be approaching, an insufficient groundwater supply. Studies conducted on these specific groundwater areas (Norton and others, 1982; Bendixsen, 1994) offer insight into regional groundwater movement and trends. 


\section{Description of the Study Area}

The Mayfield study area (fig. 1) spans parts of Ada and Elmore Counties between Boise and Mountain Home, Idaho. A large portion of the study area is slated for development, including an area that lies north of U.S. Interstate Highway 84 and south of the Danskin Mountains in the upper Indian Creek drainage basin. Land surface altitude within the study area ranges from $6,700 \mathrm{ft}$ in the Danskin Mountains to $3,140 \mathrm{ft}$ near the historic town of Orchard in the southern part of the study area.

\section{Land Use}

The study area is sparsely populated, but it is being considered for potential development. As of October 2008, 11 water rights applications were pending for planned communities in or near the study area (Idaho Department of Water Resources, written commun., 2011). The ecoregion of the area is defined as a mixture of Mountain Home Uplands and Foothills Shrublands-Grasslands (National Agricultural Statistics Service, 2011). Non-developed land is covered by shrub land or pasture area. Additionally, the area has a small amount of agricultural land use for hay, alfalfa, corn, winter wheat, and sugar beets. The foothills and benches are dry, generally treeless, and covered by shrubs and grasses. Most of the land is used for grazing, but a small part of the land has been developed for residential use (U.S. Department of Agriculture, 2012).

\section{Climate}

Climate in the Mayfield study area falls into two classifications under the modified Köppen system: the plains below the foothills are classified as BSk, and the foothills are classified as Dsa (Godfrey, 2000; Peel and others, 2007). For the plains, BS indicates an arid steppe climate, and $\mathrm{k}$ indicates that the mean annual air temperature is less than $17.8^{\circ} \mathrm{C}$. For the foothills, Dsa identifies a cold climate with dry, hot summers (Peel and others, 2007).

Four weather stations surrounding the study area have sufficient long-term data for climatic calculations (table 1). As of 2012, one active Agrimet station is within $25 \mathrm{mi}$ of the study area: Boise, Idaho (Bureau of Reclamation, 2006). Additionally, four Natural Resources Conservation Service snow-survey sites are in or adjacent to the study area: three are instrumented SNOTEL sites, and the other is a snow course site (Natural Resources Conservation Service, 2010).

Long-term mean air temperatures for selected National Weather Service stations are listed in table 1. Mean annual air temperatures at the four stations range from $10.7^{\circ} \mathrm{C}$ at Boise Weather Service Field Office (WSFO) Airport to $11.5^{\circ} \mathrm{C}$ at Boise Lucky Peak Dam. The coldest month in the area is January, with mean low air temperatures ranging from $-6.3^{\circ} \mathrm{C}$ at Mountain Home and Grand View $2 \mathrm{~W}$ to $-5.4^{\circ} \mathrm{C}$ at Boise WSFO Airport. Typically, the warmest month is July, with mean high air temperatures ranging from $32.5^{\circ} \mathrm{C}$ at Boise WSFO Airport to $34.6^{\circ} \mathrm{C}$ at Grand View $2 \mathrm{~W}$. Mean annual precipitation ranges from 7.15 in. at Grand View $2 \mathrm{~W}$ to 13.7 in. at Boise Lucky Peak Dam (table 1). July and August typically are the driest months; November, December, and January are the wettest (Western Regional Climate Center, 2008).

Table 1. Summary of data from selected weather stations near the Mayfield area, southwestern Idaho, 2011-12.

[Climate data from Western Regional Climate Center (2008). Abbreviations: ${ }^{\circ} \mathrm{C}$, degrees Celsius; in., inch; ft, foot; NAVD 88, North American Vertical Datum of 1988; WSFO, Weather Service Field Office]

\begin{tabular}{|c|c|c|c|c|c|c|c|c|c|c|}
\hline \multirow{2}{*}{$\begin{array}{l}\text { Station name } \\
\text { and No. }\end{array}$} & \multirow[b]{2}{*}{ Latitude } & \multirow[b]{2}{*}{ Longitude } & \multicolumn{3}{|c|}{$\begin{array}{l}\text { Mean air temperature } \\
\left({ }^{\circ} \mathrm{C}\right)\end{array}$} & \multirow{2}{*}{$\begin{array}{l}\text { Mean total } \\
\text { precipi- } \\
\text { tation } \\
\text { (in.) }\end{array}$} & \multirow{2}{*}{$\begin{array}{l}\text { Mean total } \\
\text { snowfall } \\
\text { (in.) }\end{array}$} & \multirow{2}{*}{$\begin{array}{l}\text { Altitude } \\
\text { (ft above } \\
\text { NAVD 88) }\end{array}$} & \multicolumn{2}{|c|}{ Dates in operation } \\
\hline & & & $\begin{array}{c}\text { July } \\
\text { maximum }\end{array}$ & $\begin{array}{c}\text { January } \\
\text { minimum }\end{array}$ & Annual & & & & $\begin{array}{l}\text { Starting } \\
\text { date }\end{array}$ & $\begin{array}{l}\text { Ending } \\
\text { date }\end{array}$ \\
\hline $\begin{array}{r}\text { Mountain Home, } \\
\text { Idaho, } 106174\end{array}$ & $43^{\circ} 08^{\prime} \mathrm{N}$ & $115^{\circ} 42^{\prime} \mathrm{W}$ & 34.0 & -6.3 & 10.8 & 10.6 & 11 & 3,190 & 08-01-1948 & $10-31-2007$ \\
\hline $\begin{array}{l}\text { Grand View } 2 \mathrm{~W}, \\
\text { Idaho, } 103760\end{array}$ & $43^{\circ} 00^{\prime} \mathrm{N}$ & $116^{\circ} 08^{\prime} \mathrm{W}$ & 34.6 & -6.3 & 11.2 & 7.15 & 5.4 & 2,400 & 04-01-1933 & $12-31-2005$ \\
\hline $\begin{array}{l}\text { Boise Lucky Peak } \\
\text { Dam, Idaho, } 101018\end{array}$ & $43^{\circ} 33^{\prime} \mathrm{N}$ & $116^{\circ} 04^{\prime} \mathrm{W}$ & 33.1 & -6.2 & 11.5 & 13.7 & 4.9 & 2,840 & $01-12-1951$ & $12-31-2005$ \\
\hline $\begin{array}{l}\text { Boise WSFO } \\
\text { Airport, Idaho, } \\
101022\end{array}$ & $43^{\circ} 34^{\prime} \mathrm{N}$ & $116^{\circ} 13^{\prime} \mathrm{W}$ & 32.5 & -5.4 & 10.7 & 11.8 & 20 & 2,840 & 01-01-1940 & $12-31-2005$ \\
\hline
\end{tabular}




\section{Geology}

The Mayfield study area is on the edge of the western SRP, located between the northern Rocky Mountain physiographic province and the northern Basin and Range Extensional Province (Wood, 1994). The western SRP is a northwestern-trending intracontinental rift basin, 28-mi wide and 155-mi long. It was formed by volcanism associated with the passage of the Yellowstone plume system during the late Cenozoic Period, and by Basin and Range extension during the Pleistocene (Shervais and others, 2002).

The general geology of the western SRP consists of Cretaceous biotite-granodiorite Idaho Batholith basement rock, overlain by 1.6-2.7 mi of Miocene basalt, and covered by lacustrine and fluvial sediments (Mitchell, 1981; Wood and Anderson, 1981; Mayo and others, 1984; Whitehead, 1986; Wood and Clemens, 2002). The bulk of sediments in the study area were deposited during the Pliocene by Lake Idaho, a long-lived system that once filled the western SRP to an altitude of 3,600 ft (Shervais and others, 2002). Because the study area is located on the edge of the basin, mostly fine-grained, near-shore Lake Idaho lacustrine sediments are present (Welhan, 2012). Atop the sand and Lake Idaho sediments sit sand and pebbles derived from the granitic highlands (Phillips and others, 2012).

Idaho group sands in the Mayfield area are interfingered with Pleistocene basalt flows and dominate the subsurface, increasing in thickness to the south (Liberty, 2012). The Mayfield study area has outcrops of Eocene rhyolitic tuff and lava, as well as outcrops of Miocene basaltic tuff and tuffaceous sandstone near the Danskin Mountains. Basaltic units in the local area include the Slaters Flat shield Volcano, as well as Pleistocene and older basalt flows that are common in the western SRP (Phillips and others, 2012; Welhan, 2012). Sands and gravels contain quartz, orthoclase, plagioclase, biotite, and mafic minerals; some grains are coated with carbonate-silica to form oolites (Phillips and others, 2012).

\section{Hydrogeology}

The main water-bearing units in the Mayfield area are Idaho group sands and underlying fractured basalts. Welhan (2012) used drillers' reports to infer the locations of some of the principal water-bearing zones in the study area. Water is in shallow, perched zones (hereafter called the perched aquifer) that may or may not be laterally continuous; water is also in a more continuous, unconfined deep aquifer below the perched water table (hereafter called the deep aquifer) (Welhan, 2012). At this date (2013), confining units have not been identified, although Welhan (2012) suggests that cementation of sand and silica could serve as a local confining unit if laterally continuous. Additionally, clay layers from near-shore lake deposits could form discontinuous impermeable layers.

Multiple studies have concluded that groundwater generally flows southwestward from the study area towards the Snake River (SPF Engineering, 2007a; Welhan, 2012). A hydraulic gradient of about $133 \mathrm{ft} / \mathrm{mi}$ towards the southwest was determined from cross sections, but did not differentiate between shallow and deep water-bearing zones (S.H. Wood, Boise State University, unpub. report, 1996). Hydraulic gradients in the deep aquifer are steepest about 4-5 mi southwest from the range front (Welhan, 2012). The steepening of the hydraulic gradient away from the range front suggests that geologic controls (buried faults) or local recharge may play a role in shaping the local water table.

It has been suggested that faulting controls groundwater flow in the area (Liberty, 2012; Welhan, 2012). The northeast-trending Blacks Creek fault offset Miocene dikes (Phillips and others, 2012), which may suggest similar faulting. Liberty (2012) suggested that buried faults exist near the range front. Northeast-trending, high-angle faults and shear zones in the Idaho Batholith exist in the Batholith to the north of the study area and may influence the groundwater flow in the study area (O'Neil and Lopez, 1985) by facilitating flow between surface water, the perched aquifer, and the deep aquifer. Welhan (2012) speculates that contact between granite and sediment near the mountain front may be cut by two small displacement faults; these faults could possibly provide a mechanism for surface water or perched groundwater to move into the deep aquifer. Faults also could impede groundwater flow, forming a barrier between aquifer units, or possibly breaking up the perched aquifer into discontinuous perched water bodies.

Several possible sources of recharge to the Mayfield study area have been suggested. These include infiltration of precipitation in excess of evapotranspiration, seepage losses from ephemeral streams that flow onto alluvial fans, mountain front recharge, and upwelling of water from interbasin flow or deep geothermal waters (SPF Water Engineering, 2007a; Welhan, 2012). SPF Water Engineering (2007a) estimated recharge and evapotranspiration rates in the area and determined that only a small amount of precipitation actually infiltrates and contributes to recharge in the study area. No studies to date have quantified seepage from surface water into alluvial fans or mountain system underflow. Williams and Etheridge (2013) determined that there is little to no seepage from Indian Creek Reservoir (fig. 1) to the underlying deep aquifer. Underflow from the Idaho Batholith could also be contributing recharge to the study area; Newton (1991) considered this possibility and suggested that the amount of recharge from this source would be small due to the impermeable nature of the granitic basement rock. 
Welhan (2012) theorized that upwelling geothermal water was a potential source of recharge in the area; he used water temperatures to determine that deep wells contained as much as 20 percent geothermal water (water warmer than $16^{\circ} \mathrm{C}$ ). Welhan (2012) proposed the presence of a geothermal component in the deep aquifer from groundwater circulated at less than 1-km depth. He further postulated that seasonal factors, as well as pumping-induced hydraulic stresses, may be affecting mixing proportions. The geochemical signature of high concentrations of lithium and fluoride that characterize the Boise Geothermal system (Waag and Wood, 1987; Druschel and Rosenberg, 2000) also was detected in groundwaters of the study area, further suggesting geothermal recharge (Welhan, 2012).
Surface-water conditions vary throughout the year and generally reflect climactic conditions. The dry climate of the study area controls streamflow and the ephemeral streams in the area generally only flow in response to precipitation or snow melt. Discharge, as recorded for 2 years at the surface-water site on Indian Creek (SW1), is an excellent example of annual streamflow patterns (fig. 2). Streamflow usually peaks around precipitation and runoff events during the winter and spring months; typically surface-water flow ceases during the summer and autumn months. Similar patterns have been observed in Blacks Creek and Browns Creek.

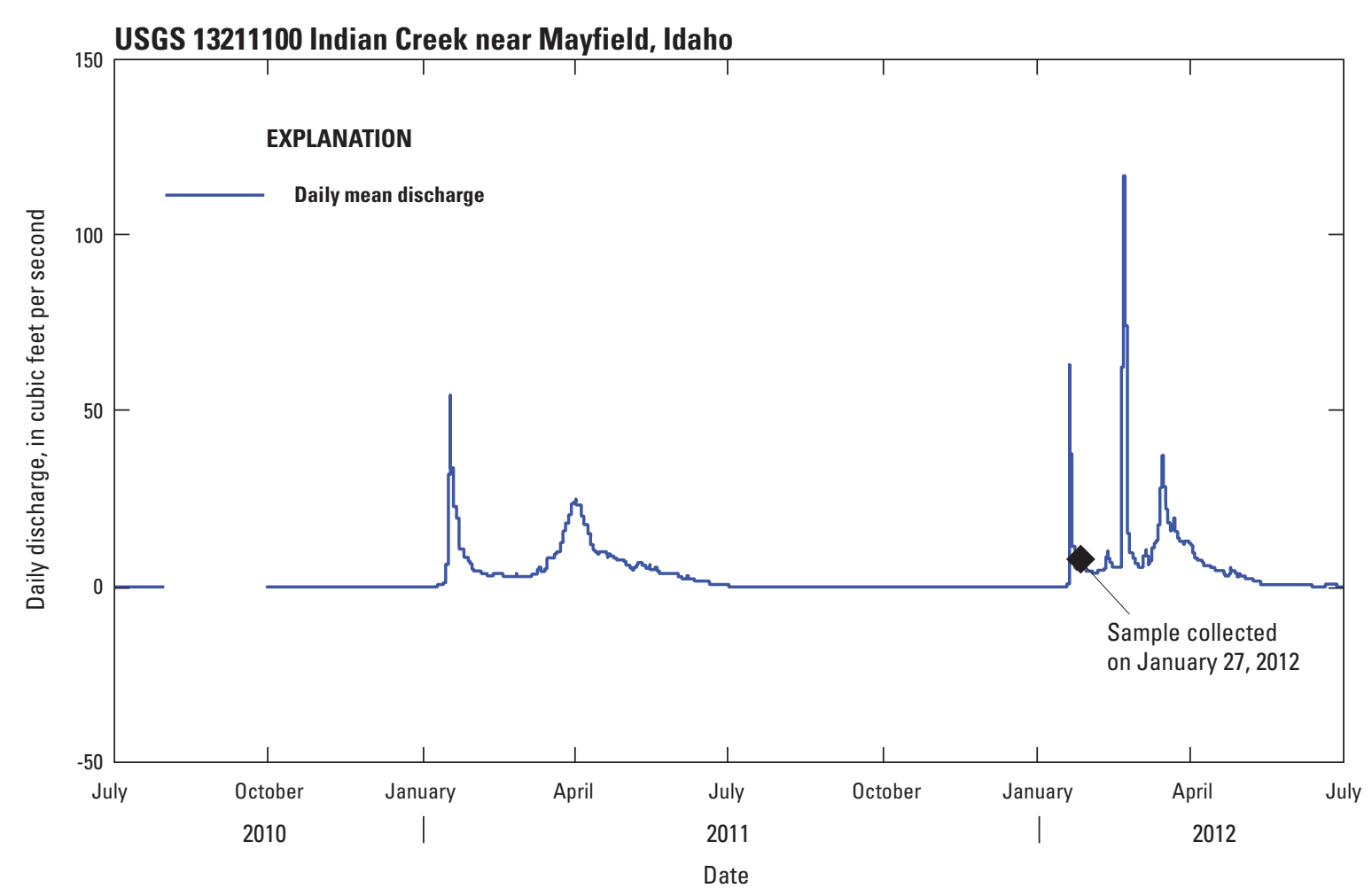

Figure 2. Discharge at U.S. Geological Survey streamflow-gaging station Indian Creek near Mayfield, Idaho, July 2010-July 2012. 


\section{Methods}

Data for this study were collected from wells selected by the USGS and IDWR based on location, well depth, well construction, and accessibility. Fifteen samples were collected for this study between August of 2011 and March of 2012 (fig. 1). Fourteen of the samples were from domestic, irrigation, or monitoring wells in the Mayfield area; one sample from Indian Creek was collected to characterize the water-quality characteristics of surface-water recharge (table 2). In addition to the environmental samples, two replicate samples were collected for quality-control purposes.

\section{Field Methods}

\section{Site Selection}

To characterize potential geochemical reactions along a flow path, where possible, most wells were selected along a line following the hydraulic gradient, or from near the base of the foothills southwest toward the SRP. Wells were classified by aquifer based on the definition by Welhan (2012) and by well completion information.

Table 2. Site location information for wells and surface-water sites sampled in the Mayfield area, southwestern Idaho, 2011-12.

[Depth of well and screening information obtained from well logs associated with station name. Sample names assigned based on depth and aquifer sampled. Abbreviations ft, foot; NAVD 88, North American Vertical Datum of 1988; USGS, U.S. Geological Survey; N/A, not applicable; -, no data available]

\begin{tabular}{|c|c|c|c|c|c|c|c|c|c|c|}
\hline USGS station No. & Station name & $\begin{array}{c}\text { Unique } \\
\text { station } \\
\text { identifier }\end{array}$ & Latitude & Longitude & $\begin{array}{c}\text { Altitude } \\
\text { (ft above } \\
\text { NAVD 88) }\end{array}$ & $\begin{array}{l}\text { Sample } \\
\text { date }\end{array}$ & $\begin{array}{c}\text { Sample } \\
\text { time }\end{array}$ & $\begin{array}{c}\text { Depth } \\
\text { of well } \\
\text { (ft below } \\
\text { land surface) }\end{array}$ & $\begin{array}{l}\text { Depth to water, } \\
\text { at time of } \\
\text { sampling } \\
\text { (ft below } \\
\text { land surface) }\end{array}$ & $\begin{array}{c}\text { Top of } \\
\text { screen } \\
\text { (ft below } \\
\text { land surface) }\end{array}$ \\
\hline \multicolumn{11}{|c|}{ Perched aquifer near Indian Creek Reservoir } \\
\hline 432310116001001 & 01N 04E 29DCC1 & PICR1 & $43^{\circ} 23^{\prime} 10.0^{\prime \prime}$ & $116^{\circ} 00^{\prime} 09.8^{\prime \prime}$ & " 3,359 & 08-04-2011 & 1538 & 92 & N/A & - \\
\hline \multicolumn{11}{|c|}{ Mountain system } \\
\hline 432655115543001 & 01N 05E 06CAB1 & M1 & $43266^{\prime} 54.6^{\prime \prime}$ & $11554^{\prime} 29.9^{\prime \prime}$ & 3,761 & 08-03-2011 & 1047 & 170 & 17.3 & 120 \\
\hline \multicolumn{11}{|c|}{ Perched aquifer } \\
\hline 432343115573701 & 01N 04E 27ACD2 & $\mathrm{P} 1$ & $43^{\circ} 23^{\prime} 42.8^{\prime \prime}$ & $115^{\circ} 57^{\prime} 37.0^{\prime \prime}$ & 3,429 & $11-16-2011$ & 1440 & 75 & $\mathrm{~N} / \mathrm{A}$ & 28 \\
\hline 432602115554101 & 01N 04E 12CAC2 & P2 & $43^{\circ} 26^{\prime} 02.3^{\prime \prime}$ & $115^{\circ} 55^{\prime} 41.4^{\prime \prime}$ & 3,582 & 08-02-2011 & 0950 & 95 & 44.2 & 90 \\
\hline 432507115550701 & 01N 04E 13DAC1 & P3 & $43^{\circ} 25^{\prime} 06.7^{\prime \prime}$ & $115^{\circ} 55^{\prime} 07.3^{\prime \prime}$ & 3,571 & 08-04-2011 & 1155 & 100 & 60.7 & 95 \\
\hline 432450115562401 & 01N 04E 23ABA1 & P4 & $43^{\circ} 24^{\prime} 50^{\prime \prime}$ & $115^{\circ} 56^{\prime} 24^{\prime \prime}$ & 3,517 & 08-01-2011 & 1014 & 147 & 70.5 & - \\
\hline 432501115560701 & 01N 04E 4DDAD1 & P5 & $43^{\circ} 25^{\prime} 00.8^{\prime \prime}$ & $115^{\circ} 56^{\prime} 10.3^{\prime \prime}$ & 3,530 & 08-02-2011 & 1140 & 200 & 93.8 & - \\
\hline \multicolumn{11}{|c|}{ Deep aquifer } \\
\hline 432514115555201 & 01N 04E 13CBA1 & D1 & $43^{\circ} 25^{\prime} 14.5^{\prime \prime}$ & $115^{\circ} 55^{\prime} 52.3^{\prime \prime}$ & 3,567 & 08-02-2011 & 1335 & 330 & 260 & 320 \\
\hline 432430115562001 & 01N 04E 23ADC1 & D2 & $43^{\circ} 24^{\prime} 29.6^{\prime \prime}$ & $115^{\circ} 56^{\prime} 20.0^{\prime \prime}$ & 3,483 & $11-18-2011$ & 1350 & 450 & N/A & 420 \\
\hline 432339115573801 & 01N 04E 27ACD1 & D3 & $43^{\circ} 23^{\prime} 39.2^{\prime \prime}$ & $115^{\circ} 57^{\prime} 38.7^{\prime \prime}$ & 3,429 & 08-04-2011 & 0955 & 480 & N/A & 420 \\
\hline 432306115595201 & 01N 04E 32AAB1 & D4 & $43^{\circ} 23^{\prime} 02.5^{\prime \prime}$ & $115^{\circ} 59^{\prime} 55.8^{\prime \prime}$ & 3,370 & 08-04-2011 & 1350 & 711 & $\mathrm{~N} / \mathrm{A}$ & - \\
\hline 432805116050501 & 02N 03E 34ACC1 & D5 & $43^{\circ} 28^{\prime} 05.0^{\prime \prime}$ & $116^{\circ} 05^{\prime} 04.6^{\prime \prime}$ & 3,417 & 03-29-2012 & 0945 & 861 & 710 & 780 \\
\hline 431832116010401 & 01S 04E 30ADC1 & D6 & $43^{\circ} 18^{\prime} 31.8^{\prime \prime}$ & $116^{\circ} 01^{\prime} 06.5^{\prime \prime}$ & 3,149 & $11-22-2011$ & 1317 & 960 & N/A & 870 \\
\hline 432555116033001 & 01N 03E 11DDB1 & D7 & $43^{\circ} 25^{\prime} 51.0^{\prime \prime}$ & $116^{\circ} 03^{\prime} 28.8^{\prime \prime}$ & 3,355 & $11-17-2011$ & 0945 & 1,000 & N/A & - \\
\hline \multicolumn{11}{|c|}{ Surface water } \\
\hline 13211100 & $\begin{array}{l}\text { Indian Creek near } \\
\text { Mayfield, Idaho }\end{array}$ & SW1 & $43^{\circ} 25^{\prime} 02^{\prime \prime}$ & $115^{\circ} 53^{\prime} 51^{\prime \prime}$ & 3,620 & $01-27-2012$ & 0930 & N/A & N/A & N/A \\
\hline
\end{tabular}


One sample was collected from the mountain system (decomposed granite), five samples were collected from the perched aquifer (generally shallower than $200 \mathrm{ft}$ depth), and seven samples were collected from the deep aquifer (generally deeper than $300 \mathrm{ft}$ depth). One sample was collected from a locally-perched aquifer near Indian Creek Reservoir, and one surface-water sample was collected from Indian Creek. Unique site identifiers were assigned to each sample location based on which aquifer the water was collected from and can be viewed next to the well's station name in tables $2-\underline{9}$.

\section{Sample Collection}

For groundwater samples, a closed path was established between the well and sampling equipment to prevent contact with the atmosphere. Water from wells equipped with an existing submersible pump was sampled as close to the wellhead as possible using the existing plumbing. One monitoring well did not have a dedicated submersible pump, necessitating the use of a portable electric Grundfos Redi-Flo ${ }^{\circledR}$ submersible pump and tygon tubing.

Field parameters (specific conductance, $\mathrm{pH}$, water temperature, and dissolved oxygen) were measured at each well site using portable meters. Meters were placed in a flow-through chamber and connected to the discharge line from the well. Samples were collected after at least three casing volumes of water were purged from the well and field parameters were stable.

Samples were collected in appropriate containers and preserved in accordance with the procedures specified in the USGS National Field Manual (U.S. Geological Survey, variously dated). Bottles for oxygen-18 and hydrogen-2 analysis were filled with no head space. Bottles for physical parameter analyses were rinsed three times, and samples were collected without filtration. Bottles for nutrient, metal, major ion, and carbon-13 and carbon-14 analyses were rinsed three times and filled using water filtered through a 0.45-micron capsule filter. Carbon-14 samples were collected in a safety-coated 1-L glass bottle and shipped chilled. Chlorofluorocarbon (CFC) and dissolved gas samples were collected using copper tubing. Field procedures followed those outlined by the USGS CFC and dissolved gas guidelines (U.S. Geological Survey, 2006, 2009). CFC samples were collected in glass bottles that were capped with aluminum foil-lined caps, sealed with electrical tape, and stored upside down. Dissolved gas samples were collected in glass bottles and plugged; gasses were allowed to escape during sampling through a hypodermic needle injected through the plug.

The surface-water sample was a grab sample collected from the centroid of the stream near the streamgage. Field parameters were measured in-situ using portable meters. The surface-water sample was collected and preserved according to procedures specified in the USGS National Field Manual (U.S. Geological Survey, variously dated); surface-water sample collection did not involve the collection of dissolved gases or CFCs.

\section{Quality Assurance/Quality Control}

This study followed the quality-assurance plan for the collection of water-quality samples by the USGS Idaho Water Science Center (Mark Hardy, written commun., 2008). Meters were calibrated in the field each day before use. All field equipment was cleaned using established protocols prior to use.

Replicate groundwater samples were collected from two wells to identify and quantify the variability (i.e., random error) of all aspects of the sampling and analysis process. Replicates (also called replicate pairs) consisted of two water samples, an environmental sample and a replicate sample, with the replicate sample collected immediately after collection of the environmental sample. The replicate samples were subjected to identical field processing and laboratory analysis procedures.

At both sites, the analyte concentrations in the environmental and replicate samples were evaluated using the relative percent difference equation:

$$
\mathrm{RPD}=\left[\left(\mathrm{V}_{\mathrm{S}}-\mathrm{V}_{\mathrm{R}}\right) /\left(\left(\mathrm{V}_{\mathrm{S}}+\mathrm{V}_{\mathrm{R}}\right) / 2\right)\right] \times 100
$$

where

RPD is the relative percent difference,

$V_{S}$ is the value of the primary sample, and

$V_{R}$ is the value of the replicate sample.

For the replicate samples collected during this study, the RPD for all analytes was below 10 percent, indicating good reproducibility in sample collection techniques and laboratory analysis. Some analyte concentrations were below the reporting limit and a RPD could not be calculated; however, if both the original and replicate sample plotted near or below the reporting limit, the results were considered acceptable.

\section{Laboratory Methods}

Samples for major ion, nutrients, metals, and physical parameters were analyzed at the USGS National Water Quality Lab (NWQL) in Denver, Colo. Laboratory procedures are described by Fishman and Friedman (1989) and Fishman (1993). 
Stable isotopes of oxygen and hydrogen were analyzed at the USGS Reston Stable Isotope Laboratory in Reston, Va. Samples were collected in glass bottles with polyseal caps. The hydrogen equilibration technique (Coplen and others, 1991) was used to analyze the hydrogen-isotope ratio. Results for stable isotopes are expressed in units of per mil (\%o, parts per thousand) and expressed in delta notation $(\delta)$ as derived from comparing the sample to Vienna Standard Mean Ocean Water (VSMOW) (Coplen, 1996). The two standard deviation accuracy of oxygen and hydrogen isotopes were 0.2 and $2 \%$, respectively (Révész and Coplen, 2008a, 2008b).

Carbon-13 $\left({ }^{13} \mathrm{C}\right)$ and carbon-14 $\left({ }^{14} \mathrm{C}\right)$ isotope samples were analyzed at the National Ocean Sciences Accelerator Mass Spectrometry Facility in Woods Hole, Mass. Only groundwater samples were analyzed for carbon isotopes. Carbon dioxide gas was extracted from each sample by acid hydrolysis and reduced to graphite for accelerator mass spectrometry. Using this technique, samples of carbon up to 50,000 years old with an error of less than 0.4 percent modern carbon (pmc) can be analyzed (Woods Hole Oceanographic Institution, 2003). Carbon-13 results are reported in per mil (\%o, parts per thousand), and expressed in delta notation $(\delta)$ as compared to a standard reference sample of Vienna Pee Dee Belmanite (VPDB) (Woods Hole Oceanographic Institution, 2003).

CFCs and dissolved gases were analyzed at the USGS Reston Chlorofluorocarbon Laboratory in Reston, Va. CFC results were determined in the laboratory using a purge-andtap gas chromatography procedure with an electron capture detector (U.S. Geological Survey, 2012a). Dissolved gas samples were allowed to equilibrate with headspace with the resultant gas analyzed on a gas chromatograph (U.S. Geological Survey, 2012b).

\section{Flow-Path Cross Plots}

Cross plots were constructed to show changes in groundwater geochemistry along a possible flow path. A relative position for a well along a flow path was determined based on its position in relation to other wells in the same aquifer. Wells are grouped by aquifer and may not represent the actual flow path of water. Sites D5 and D7 are plotted along the deep aquifer flow path, but may be influenced by different water altogether than the other deep wells (D1-D4) since they are not in the upper Indian Creek watershed (fig. 1). Samples are plotted this way to demonstrate chemical changes that occur as water moves through each aquifer. Sample PICR1 was left off of these plots due to its anomalous water quality and assumed lack of connectivity with other samples.

\section{Carbon-14 Age Interpretation and Correction}

Results for carbon-14 are reported in pmc, and mean residence times are calculated from the decay equation (Clark and Fritz, 1997). Samples reported as "modern" imply that recharge to groundwater occurred later than 1950 (Woods Hole Oceanographic Institution, 2003). Uncorrected carbon-14 ages were calculated by the laboratory using the decay equation:

$$
\mathrm{t}=-8267 \ln \left(\mathrm{a}^{14} \mathrm{C} / \mathrm{a}_{\mathrm{o}}{ }^{14} \mathrm{C}\right)
$$

where

$t$ is the age of the water sample, in years,

$a^{14} \mathrm{C}$ is the measured carbon-14 activity in, and groundwater, and

$\mathrm{a}_{\mathrm{o}}{ }^{14} \mathrm{C}$ is the carbon-14 activity in modern soil (set as $100 \mathrm{pmc}$ ).

The decay equation does not account for carbonate dissolution. To account for potential carbonate dissolution and to obtain a more accurate residence time, carbon-14 measurements were corrected using a $\delta^{13} \mathrm{C}$ mixing model (Clark and Fritz, 1997). The $\delta^{13} \mathrm{C}$ mixing model (developed by Pearson and White, 1967) is a useful tool for correcting carbon-14 age calculations; this model can reliably correct carbon-14 dilution caused by the large difference in $\delta^{13} \mathrm{C}$ between soil-derived dissolved inorganic carbon (DIC) and carbonate minerals in the aquifer. Hutchings and Petrich (2002) suggested that relatively young basin margin waters need to be corrected using an open-system carbon-13 mixing model. The $\delta^{13} \mathrm{C}$ mixing model-correction factor is calculated using the following equation:

$$
\mathrm{q} \delta^{13} \mathrm{C}_{\text {DIC }}=\left(\delta^{13} \mathrm{C}_{\text {DIC }}-\delta^{13} \mathrm{C}_{\text {carb }}\right) /\left(\delta^{13} \mathrm{C}_{\text {rech }}-\delta^{13} \mathrm{C}_{\text {carb }}\right)
$$

where

$$
\begin{aligned}
& 9 \delta^{13} \mathrm{C}_{\mathrm{DIC}} \text { is the dilution factor, } \\
& \delta^{13} \mathrm{C}_{\mathrm{DIC}} \text { is the measured } \delta^{13} \mathrm{C} \text { of groundwater, } \\
& \delta^{13} \mathrm{C}_{\text {carb }} \text { is the } \delta^{13} \mathrm{C} \text { of calcite being dissolved } \\
& \text { (assumed to be } 0 \% \text { by Hutchings } \\
& \text { and Petrich [2002]), and } \\
& \delta^{13} \mathrm{C}_{\text {rech }} \text { is the } \delta^{13} \mathrm{C} \text { of DIC in the infiltrating } \\
& \text { groundwaters, defined as: }
\end{aligned}
$$




$$
\delta^{13} \mathrm{C}_{\text {rech }}=\delta^{13} \mathrm{C}_{\text {soil }}+\varepsilon^{13} \mathrm{C}_{\mathrm{DIC}-\mathrm{CO}_{2} \text { (soil) }}
$$

where

$$
\begin{aligned}
& \delta^{13} \mathrm{C}_{\text {soil }} \text { is the } \delta^{13} \mathrm{C} \text { of soil } \mathrm{CO}_{2} \text { (assumed to } \\
& \text { be }-23 \% \text {, as suggested by } \\
& \text { Hutchings and Petrich [2002]), and } \\
& \varepsilon^{13} \mathrm{C}_{\mathrm{DIC}-\mathrm{CO}_{2} \text { (soil) }} \text { is the } \mathrm{pH} \text { dependent enrichment } \\
& \delta^{13} \mathrm{C}_{\text {soil }} \text { by fractionation between } \\
& \text { soil } \mathrm{CO}_{2} \text { and } \mathrm{DIC}_{\text {soil }} \text {. }
\end{aligned}
$$

$\mathrm{pH}$ enrichment factors were calculated by an estimated fraction factor from Clark and Fritz (1997, table 5.2) based on sample temperature and are presented with carbon-14 data. Dilution factors were then calculated and multiplied by the uncorrected age to obtain a corrected age for carbon-14.

Carbon-14 ages are best understood as relative ages due to the uncertainties used in correcting carbon-14 values. Corrected ages are an estimate of the mean residence time of the water; however, many assumptions went into making calculations that introduce uncertainties to the age. Assumed values incorporate the carbon-13 values of soil and carbonate in the system, values could actually vary greatly from the numbers used in this model. Changing one of these carbon-13 end members could change the dilution factor and corrected age significantly. Additionally, other assumptions add uncertainty to this model. Atmospheric carbon-14 activities have changed throughout time, but for simplification of calculations, this number was set to a static 100 pmc. Paleorecharge conditions may have been different than current conditions, which would greatly affect the fractionation factors and therefore the carbon-13 value of the sample; recharge conditions were assumed constant for the correction model. Due to the amount of assumptions involved, it is difficult to quantify the amount of uncertainty associated with a given carbon-14 value. One must remember that corrected carbon-14 ages are most powerful when comparing multiple samples.

\section{CFC Calibration Using Dissolved Gas Data}

Analyses of select dissolved gases in groundwater $\left(\mathrm{N}_{2}\right.$, $\mathrm{Ar}, \mathrm{CH}_{4}, \mathrm{O}_{2}$, and $\mathrm{CO}_{2}$ ) provide gas concentrations and excess air concentrations, allowing for identification of recharge conditions and estimates of recharge temperature. Excess air concentrations and recharge temperature estimates are used in the analysis of CFC data to reduce uncertainty in the calculated recharge dates. Modeled recharge dates are based on the time that groundwater became isolated from the unsaturated zone and entered the aquifer (Plummer and others, 1993).

Recharge altitudes used in temperature and CFC modeling are estimates of where recharge occurred. Because of the uncertainty associated with the altitude estimate, a sensitivity analysis was used to determine how variations in the recharge altitude would affect the CFC results. The minimum recharge altitude used was that of the well, and the maximum recharge altitude used was $6,700 \mathrm{ft}$ (a high altitude in the Danskin Mountains). The range of recharge altitudes resulted in a maximum temperature difference of $5.8^{\circ} \mathrm{C}$. The $\mathrm{CFC}$ model was recalibrated using the range of recharge temperatures and altitudes, resulting in a variation of less than 10 years in the recharge dates. Thus, changing recharge altitude and temperature did not affect the presence of CFCs and the interpretation related to their presence in groundwater.

Recharge dates were determined from CFC

concentrations and were calibrated with recharge temperature and altitude information. If two different recharge temperatures were determined from dissolved gas samples, the average of the two temperatures was used in the CFC model. Five CFC samples were collected in the field at each site, but only $2-3$ samples from each site were analyzed in the laboratory.

\section{Geochemical Modeling}

The computer program NETPATH (Plummer and others, 1994) was used to simulate the change in chemical composition of groundwater as it moves along a flow path from an initial well (upgradient) to a final well (downgradient), and to calculate travel times using groundwater ages determined with corrected carbon-14 ages. NETPATH models were constrained by the mineralogy of the aquifer and mineral saturation indices. Models were limited to the elements carbon, calcium, sodium, magnesium, silica, fluoride, iron, potassium, aluminum, as well as by carbon-13 values. Mineral phases were limited to a very simple mineralogy including calcite, potassium feldspar, biotite, fluorite, calcium montmorillinite, $\mathrm{CO}_{2}$ gas, pyrite, $\mathrm{SiO}_{2}$, and plagioclase with 45 percent anorthite composition. The mineral phases included in modeling efforts are representative of dominant mineralogy in the study area. Mineral phases were based on the presence of silicate minerals identified by Wood and Low (1988) and Welhan (2012). However, many other minerals could exist along the flow path; including additional minerals may have generated additional valid models. The model simulation results presented in this report are one representation of likely geochemical interactions between wells.

Carbon-13 values that were incorporated into flowpath models were taken from previous modeling efforts in the nearby Treasure Valley and assumed to be valid; the $\delta^{13} \mathrm{C}$ value of soil $\mathrm{CO}_{2}$ was assumed to be $-23 \%$, and the $\delta^{13} \mathrm{C}$ value of dissolved calcite was assumed to be $0.0 \%$, as suggested by Hutchings and Petrich (2002). In NETPATH models, just as in carbon-14 models, there is much uncertainty when dealing with carbon-13 and carbon-14 values and unknowns. Flow paths were simulated from an upgradient well to a downgradient well, and from the surface-water sample to a downgradient well. The groundwater sample 
collected from the perched aquifer well near Indian Creek (PICR1) was not included in any of the simulations because its unique chemistry indicated that it was not a representative well for flow-path modeling efforts.

Mixing models were used to examine potential sources of recharge to the area. For these models, an upgradient well was mixed with an input water to result in the geochemistry found at the final well. Input sources to mixing models included another well or surface water (represented by the Indian Creek surface-water sample). In addition models were developed to incorporate the chemistry of geothermal water into the flow path. Water from an upgradient well was mixed with a chemical composition representative of a hot spring from the South Fork Payette geothermal system (Sacajawea Hot Spring) (Druschel and Rosenberg, 2000) or a chemical composition representative from the Boise Geothermal Aquifer (Berkeley Group, Inc., 1990). Geochemistry from these two hot springs is typical of geothermal water from different areas in the Idaho Batholith and may represent upwelling geothermal water; these mixing models are used to simulate the chemical evolution of water from the mixing of upgradient groundwater with geothermal water and mineral interaction within the aquifer. For models incorporating surface water, carbon-13 was not used as a constraint due to unknown values from this input. Many invalid mixing models suggested the precipitation of carbon dioxide along a flow path; this was not considered a likely reaction due to low saturation indices in individual wells. Model simulation results included mineral reactions and percent contribution from each aquifer; if multiple models were possible, a range of contribution percentage from each aquifer was presented.

Geochemical models were considered successful only if they produced a likely geochemical output. Any models that produced an unlikely geochemical reaction (such as precipitation of potassium feldspar) were considered unsuccessful and invalid models. In addition, modeled carbon isotope values were used to check the validity of the geochemical model. Modeled carbon-13 values were generated by mass balance and reflected the likely trend of isotopic evolution. Calculating carbon- 13 values involved comparing the sensitivity of isotopic values at the downgradient well to the uncertainties associated with the isotopic data for the geochemical end members (carbon dioxide and calcite). Therefore, for a model to be considered valid, simulated carbon- 13 values were required to match the observed values.

\section{Cross Section Construction}

Groundwater was assumed to flow to the southwest, approximately perpendicular from the range front. A cross section (A-A', fig. 1) along an approximate flow path was constructed using well completion information and a cross section from Wellhan (2012). The cross section mimics one of the current hydrological conceptual models and allows display of geochemical changes with depth; another valid conceptual model shows the perched aquifer being laterally discontinuous. Flow paths from well to well within this cross section are consistent with water level data which indicate groundwater flows to the southwest; this conceptualization is consistent with that of Wellhan (2012).

\section{Concentration and Distribution of Geochemical Tracers}

Relations and spatial patterns in water quality that result from reactions of groundwater with aquifer matrix along a flow path and from mixing of different sources of recharge are often evident in physical parameters and major-ion chemistry. In this study, field parameters (table 3) varied between water samples, depending on which aquifer and at what depth the sample was collected. Field measurements of $\mathrm{pH}$ ranged from 6.6 to 8.1, with higher values in the deep aquifer.

Table 3. Field parameter values for water samples collected in the Mayfield area, southwestern Idaho, 2011-12.

[Abbreviations $\mathrm{CaCO}_{3}$, calcium carbonate; ${ }^{\circ} \mathrm{C}$, degrees Celsius; $\mu \mathrm{S} / \mathrm{cm}$, microsiemens per centimeter; $\mathrm{mg} / \mathrm{L}$, milligram per liter; -, no data available]

\begin{tabular}{|c|c|c|c|c|c|}
\hline $\begin{array}{l}\text { Unique } \\
\text { station } \\
\text { identifier }\end{array}$ & pH & $\begin{array}{c}\text { Specific } \\
\text { conductance } \\
\text { ( } \mathrm{S} / \mathrm{cm})\end{array}$ & $\begin{array}{c}\text { Dissolved } \\
\text { oxygen } \\
\text { (mg/L) }\end{array}$ & $\begin{array}{c}\text { Water } \\
\text { temperature, } \\
\left({ }^{\circ} \mathrm{C}\right)\end{array}$ & $\begin{array}{c}\text { Alkalinity, } \\
\text { (mg/L } \\
\left.\mathrm{CaCO}_{3}\right)\end{array}$ \\
\hline \multicolumn{6}{|c|}{ Perched aquifer near Indian Creek Reservoir } \\
\hline PICR1 & 7.1 & 1,120 & 5.85 & 13.0 & 277 \\
\hline \multicolumn{6}{|c|}{ Mountain system } \\
\hline M1 & 6.7 & 181 & 2.08 & 14.1 & 61.7 \\
\hline \multicolumn{6}{|c|}{ Perched aquifer } \\
\hline $\mathrm{P} 1$ & 6.7 & 218 & 7.85 & 13.6 & 62.5 \\
\hline $\mathrm{P} 2$ & 6.7 & 216 & 0.48 & 13.8 & 94.0 \\
\hline P3 & 6.9 & 212 & 6.38 & 14.3 & 80.9 \\
\hline $\mathrm{P} 4$ & 6.7 & 237 & 5.88 & 14.5 & 82.1 \\
\hline P5 & 6.9 & 205 & 7.87 & 15.3 & 74.2 \\
\hline \multicolumn{6}{|c|}{ Deep aquifer } \\
\hline D1 & 6.7 & 170 & 3.01 & 17.9 & 85.1 \\
\hline D2 & 6.9 & 172 & 1.09 & 21.0 & 74.9 \\
\hline D3 & 7.4 & 177 & 6.25 & 19.1 & 81.7 \\
\hline D4 & 8.1 & 220 & 4.33 & 24.2 & 99.5 \\
\hline D5 & 7.2 & 225 & - & 21.0 & 85.7 \\
\hline D6 & 8.1 & 221 & 6.91 & 25.9 & 83.9 \\
\hline D7 & 7.5 & 217 & 6.20 & 23.4 & 100 \\
\hline \multicolumn{6}{|c|}{ Surface water } \\
\hline SW1 & 6.6 & 84.0 & 14.02 & 0.2 & 45.0 \\
\hline
\end{tabular}


Specific conductance of the surface-water sample was low $(84 \mu \mathrm{S} / \mathrm{cm})$ as a result of recent snowmelt runoff (fig. 2$)$, while groundwater generally exhibited a relatively narrow range of specific conductance between 170-225 $\mu \mathrm{S} / \mathrm{cm}$ (table 3). The three most upgradient deep aquifer wells (D1-D3) had a narrow range of conductance values $(170-177 \mu \mathrm{S} / \mathrm{cm})$, which were the lowest that were measured in the groundwater network. The mountain front well (M1) also had a relatively low specific conductance value $(181 \mu \mathrm{S} / \mathrm{cm})$. Conductance values in the perched aquifer wells were higher, varied little $(205-237 \mu \mathrm{S} / \mathrm{cm})$ and were similar to values for wells D4-D7 $(217-225 \mu \mathrm{S} / \mathrm{cm})$, the four most downgradient wells in the deep aquifer. The specific conductance of the sample collected from the perched aquifer near Indian Creek Reservoir was $1,120 \mu \mathrm{S} / \mathrm{cm}$, which was considerably higher than all of the other water samples and is considered an anomaly, relative to the regional groundwater system. Alkalinity values had a similar pattern to that of conductance, ranging from 45.0 to $277 \mathrm{mg} / \mathrm{L}$, with the lowest value in the surface water and the highest values in the sample from the perched aquifer near Indian Creek Reservoir. Water temperatures in the perched aquifer ranged from 13.6 to $15.3^{\circ} \mathrm{C}$, whereas higher temperatures $\left(17.9\right.$ to $\left.25.9^{\circ} \mathrm{C}\right)$ were measured in the deep aquifer. Warmer temperatures in the deeper wells may be the result of geothermal upwelling of warm water to the deep aquifer, or may simply be a product of the natural geothermal gradient (Welhan, 2012).

Major ion data (table 4) are used to characterize water types which help to understand the geochemical evolution of groundwater within an aquifer or along a flow path.

Water from 13 of the 14 wells sampled was a mixed-cation bicarbonate water, with calcium and sodium being the co-dominant cations. Bicarbonate was the dominant anion for all wells. The sodium bicarbonate water type in well D6 was distinctly different from any other wells sampled. There was no consistent evolution of the major-ion chemistry along either the shallow or deep flow paths.

Table 4. Major-ion concentrations in water samples collected from the Mayfield area, southwestern Idaho, $2011-12$.

[Abbreviation: LT-MDL, long term-method detection limit]

\begin{tabular}{|c|c|c|c|c|c|c|c|c|}
\hline Station name & $\begin{array}{c}\text { Unique } \\
\text { station } \\
\text { identifier }\end{array}$ & $\begin{array}{l}\text { Calcium, } \\
\text { water, } \\
\text { filtered } \\
\text { (mg/L) }\end{array}$ & $\begin{array}{l}\text { Magnesium, } \\
\text { water, } \\
\text { filtered } \\
\text { (mg/L) }\end{array}$ & $\begin{array}{c}\text { Sodium, } \\
\text { water, } \\
\text { filtered } \\
\text { (mg/L) }\end{array}$ & $\begin{array}{l}\text { Potassium, } \\
\text { water, } \\
\text { filtered } \\
\text { (mg/L) }\end{array}$ & $\begin{array}{c}\text { Chloride, } \\
\text { water, } \\
\text { filtered } \\
\text { (mg/L) }\end{array}$ & $\begin{array}{c}\text { Sulfate, } \\
\text { water, } \\
\text { filtered } \\
\text { (mg/L) }\end{array}$ & $\begin{array}{c}\text { Fluoride, } \\
\text { water, } \\
\text { filtered } \\
\text { (mg/L) }\end{array}$ \\
\hline LT-MDL & & 0.022 & 0.011 & 0.060 & 0.030 & 0.060 & 0.090 & 0.040 \\
\hline \multicolumn{9}{|c|}{ Perched aquifer near Indian Creek Reservoir } \\
\hline 01N 04E 29DCC1 & PICR1 & 110 & 31 & 82 & 3.4 & 140 & 71 & 0.16 \\
\hline 01N 05E 06CAB1 & M1 & 17 & 4.5 & 9.7 & 1.7 & 4.6 & 6.0 & 0.13 \\
\hline \multicolumn{9}{|c|}{ Perched aquifer } \\
\hline 01N 04E 27ACD2 & $\mathrm{P} 1$ & 21 & 4.6 & 15 & 2.3 & 2.8 & 7.2 & 0.22 \\
\hline 01N 04E 12CAC2 & $\mathrm{P} 2$ & 19 & 5.6 & 16 & 1.5 & 4.0 & 7.6 & 0.29 \\
\hline \multicolumn{9}{|c|}{ Deep aquifer } \\
\hline 01N 04E 13CBA1 & D1 & 16 & 4.1 & 11 & 1.6 & 3.1 & 5.2 & 0.33 \\
\hline $01 \mathrm{~N}$ 04E $23 \mathrm{ADC} 1$ & D2 & 14 & 3.6 & 18 & 1.5 & 2.3 & 8.4 & 0.23 \\
\hline 01N 04E 27ACD1 & D3 & 18 & 3.7 & 12 & 1.5 & 2.3 & 4.5 & 0.19 \\
\hline 01N 04E 32AAB1 & D4 & 18 & 2.9 & 24 & 1.5 & 3.1 & 7.6 & 0.38 \\
\hline 02N 03E 34ACC1 & D5 & 21 & 5.1 & 20 & 1.5 & 3.9 & 8.9 & 0.32 \\
\hline 01S 04E 30ADC1 & D6 & 14 & 2.0 & 28 & 5.2 & 7.6 & 12 & 0.51 \\
\hline 01N 03E 11DDB1 & D7 & 22 & 4.6 & 17 & 1.7 & 3.2 & 7.2 & 0.27 \\
\hline \multicolumn{9}{|c|}{ Surface water } \\
\hline $\begin{array}{l}\text { Indian Creek near } \\
\text { Mayfield, Idaho }\end{array}$ & SW1 & 8.1 & 1.7 & 7.5 & 1.9 & 1.5 & 3.1 & 0.11 \\
\hline
\end{tabular}


Many constituents did not show a one-directional change along the perched aquifer simulated flow path, suggesting that perched aquifer wells may not be hydrologically connected. Chemistry may also vary with depth, or be influenced by compartmentalization; however, major ion chemistry does not to fully explain this trend. A more complex flow path could exist, or wells could be separated by confining units and faulting. An alternate conceptual model of the study area suggests that the perched aquifer is laterally discontinuous;
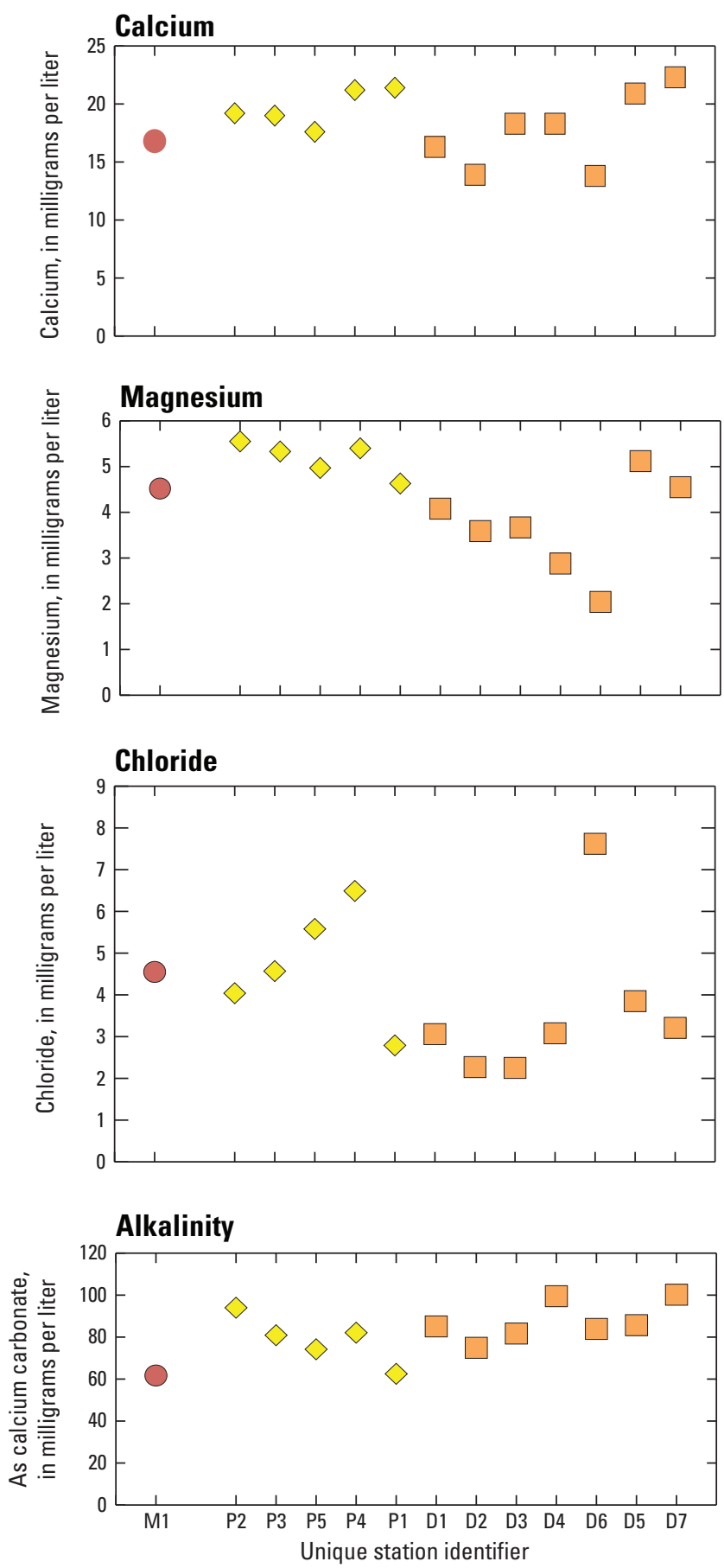

Figure 3. Major ion concentrations along a relative flow path in water samples collected in wells from the Mayfield area, southwestern Idaho, 2011-12. Results from the perched aquifer near Indian Creek Reservoir are not included. this type of aquifer would create compartmentalized and geochemically unique water and could explain variations seen in the chemistry of the perched aquifer.

The concentration of major ions variably increased or decreased along the relative flow path in the deep aquifer. As water moved downgradient in the deep aquifer, major ion concentrations varied, indicating that another type of water was being introduced (fig. 3). Samples from three deep aquifer
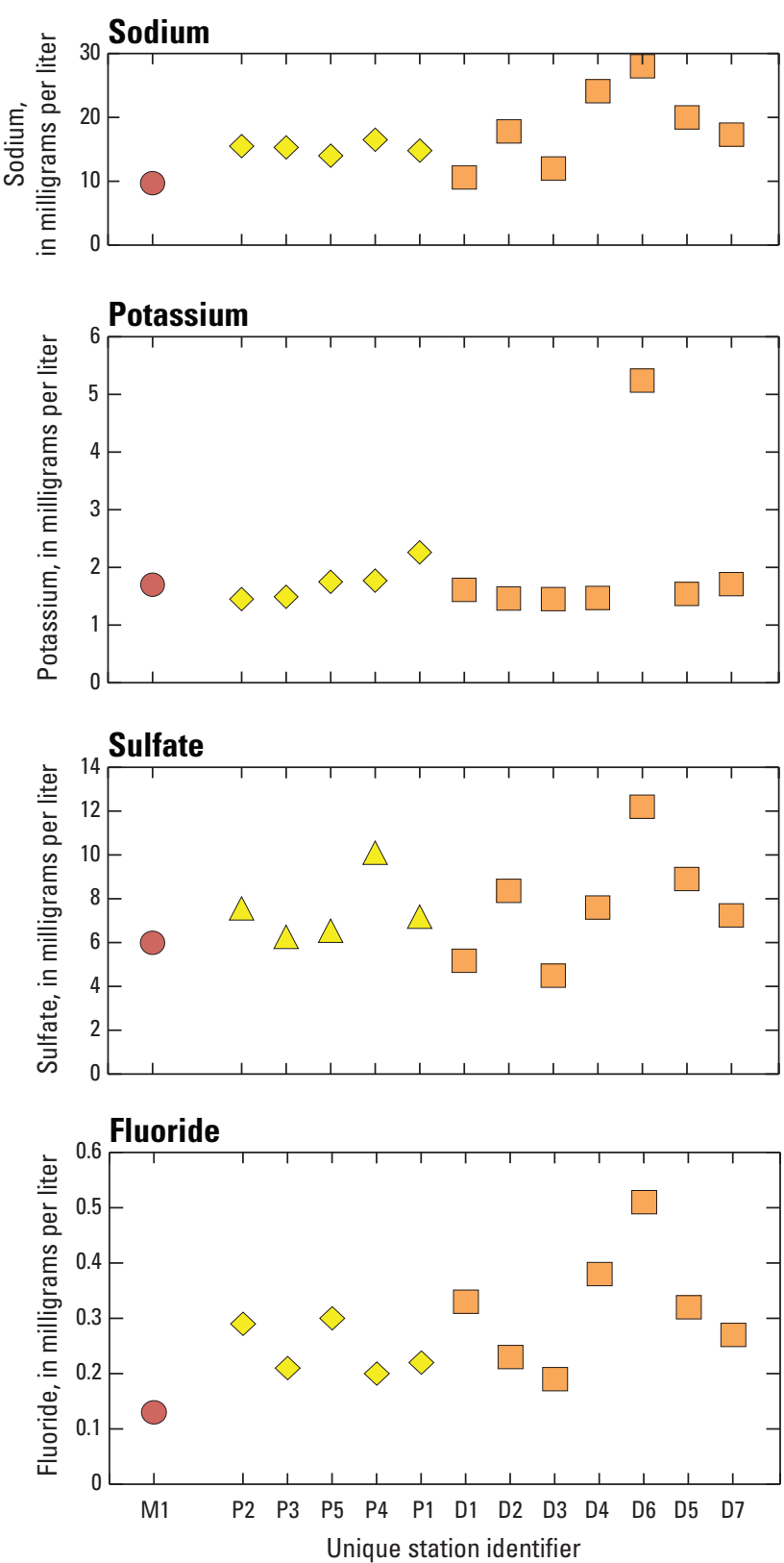

EXPLANATION

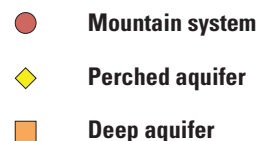


wells (D1, D2, and D3) had a lower specific conductivity than the mountain system sample or other deep aquifer samples. A change in chemistry is apparent between points D3 and D4; major ion patterns change between these two points in most flow-path cross plots, suggesting that a chemical change happens between these two wells (fig. 3; table 2). The variable concentrations of solutes in a downgradient direction may be partly due to mixing with geothermal water, or addition or removal of solutes to the solution from mineral dissolution or precipitation.

The water sample from the perched aquifer near Indian Creek Reservoir displayed an anomalous chemistry that was characterized by much higher concentrations of major ions and metals than of other water samples from all other wells. This perched aquifer well may reflect the influence of local surface-water recharge, evaporation, localized groundwater mounding, or human activity associated with septic systems and operations at a nearby commercial development; therefore, this sample is not representative of groundwater in the area, was not plotted in figure 3 , and will not be included in further discussions.

Elevated concentrations of nutrients (nitrogen and phosphorus species) greater than normal background levels can indicate the presence of water affected by human activities such as agricultural fertilizer application or wastewater disposal (Hallberg and Keeny, 1993). Identifying the sources of elevated nutrient concentrations in groundwater is important because high concentrations may adversely affect the environment and human health. Nutrient concentrations were variable in the study area (table 5); generally, they were higher in the perched aquifer than in the deep aquifer, the mountain system, or Indian Creek. Higher nutrient concentrations in the
Table 5. Nutrient concentrations in water samples collected in the Mayfield area, southwestern Idaho, 2011-12.

[Abbreviations LT-MDL, long term-method detection limit; $\mathrm{mg} / \mathrm{L},<$, less than; -, no data available]

\begin{tabular}{|c|c|c|c|c|c|}
\hline $\begin{array}{c}\text { Unique } \\
\text { station } \\
\text { identifier }\end{array}$ & $\begin{array}{c}\text { Nitrite, } \\
\text { water, filtered } \\
\text { (mg/L as } \\
\text { nitrogen) }\end{array}$ & $\begin{array}{c}\text { Nitrate, } \\
\text { water, filtered } \\
\text { (mg/L as } \\
\text { nitrogen) }\end{array}$ & $\begin{array}{c}\text { Nitrate plus } \\
\text { nitrite, } \\
\text { water, filtered } \\
\text { (mg/L as } \\
\text { nitrogen) }\end{array}$ & $\begin{array}{c}\text { Orthophosphate, } \\
\text { water, filtered } \\
\text { (mg/L as } \\
\text { phosphorus) }\end{array}$ & $\begin{array}{c}\text { Ammonia, } \\
\text { water, filtered } \\
\text { (mg/L as } \\
\text { nitrogen) }\end{array}$ \\
\hline LT-MDL & 0.001 & 0.040 & 0.040 & 0.0040 & 0.010 \\
\hline \multicolumn{6}{|c|}{ Perched aquifer near Indian Creek Reservoir } \\
\hline PICR1 & $<0.001$ & 15 & 15 & 0.083 & $<0.010$ \\
\hline \multicolumn{6}{|c|}{ Mountain system } \\
\hline M1 & $<0.001$ & 3.1 & 3.1 & 0.13 & $<0.010$ \\
\hline \multicolumn{6}{|c|}{ Perched aquifer } \\
\hline $\mathrm{P} 1$ & $<0.001$ & 7.4 & 7.4 & 0.26 & $<0.010$ \\
\hline P2 & $<0.001$ & 0.50 & 0.50 & 0.27 & $<0.010$ \\
\hline P3 & 0.002 & 3.0 & 3.0 & 0.12 & $<0.010$ \\
\hline P4 & $<0.001$ & 4.2 & 4.2 & - & $<0.010$ \\
\hline P5 & $<0.001$ & 3.1 & 3.1 & 0.14 & $<0.010$ \\
\hline \multicolumn{6}{|c|}{ Deep aquifer } \\
\hline D1 & $<0.001$ & 0.80 & 0.80 & 0.15 & $<0.010$ \\
\hline D2 & $<0.007$ & 0.14 & 0.15 & 0.12 & 0.032 \\
\hline D3 & $<0.001$ & 0.21 & 0.21 & 0.073 & $<0.010$ \\
\hline D4 & $<0.001$ & 0.11 & 0.11 & 0.020 & $<0.010$ \\
\hline D5 & $<0.001$ & 1.7 & 1.7 & 0.048 & $<0.010$ \\
\hline D6 & $<0.001$ & 0.64 & 0.64 & 0.011 & 0.020 \\
\hline D7 & $<0.001$ & 0.46 & 0.46 & 0.032 & 0.018 \\
\hline \multicolumn{6}{|c|}{ Surface water } \\
\hline SW1 & $<0.001$ & 0.09 & 0.09 & 0.066 & 0.027 \\
\hline \multicolumn{6}{|c|}{ Replicate samples } \\
\hline M1R & $<0.001$ & 3.0 & 3.0 & 0.13 & $<0.010$ \\
\hline D7R & $<0.001$ & 0.49 & 0.49 & 0.031 & 0.018 \\
\hline
\end{tabular}




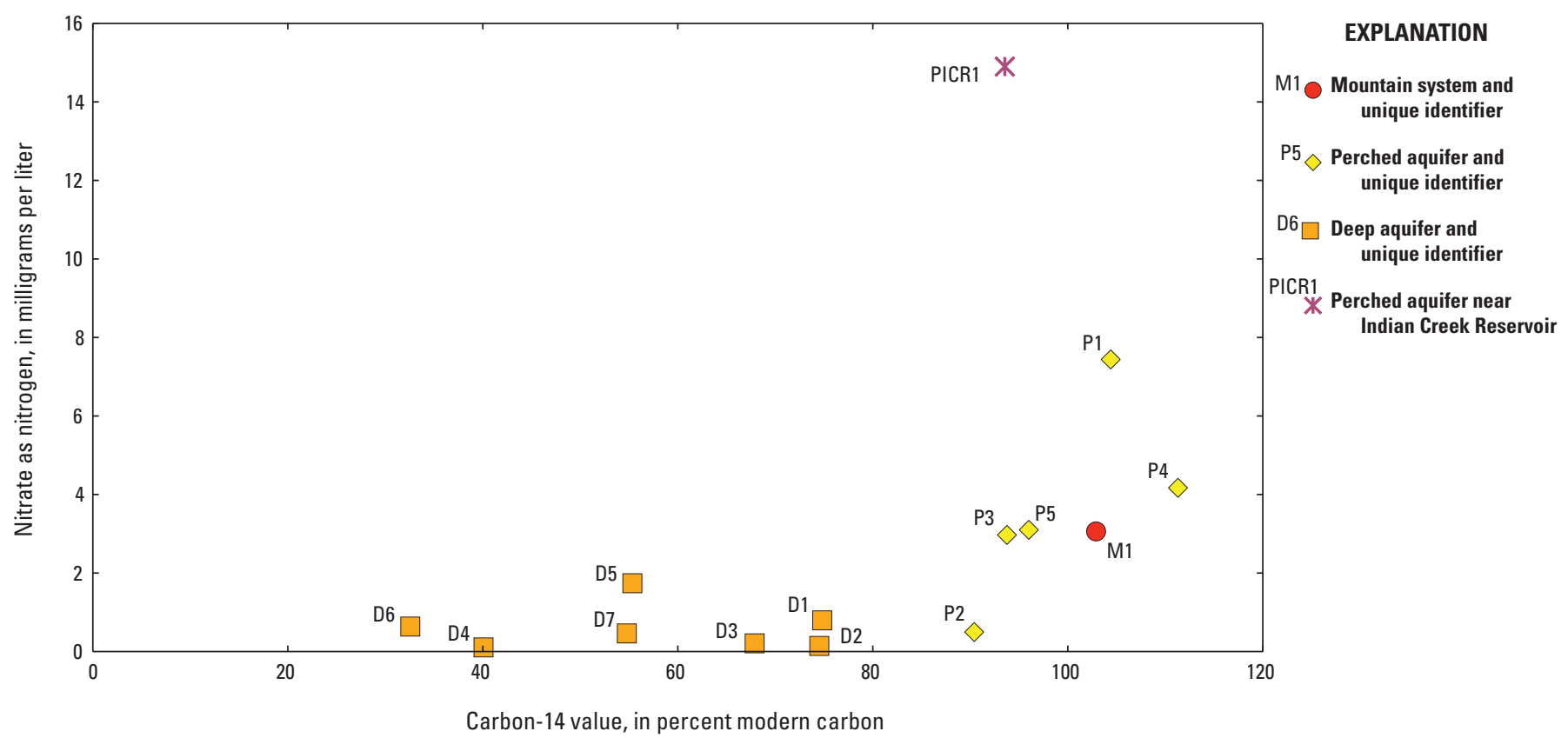

Figure 4. Nitrate concentration compared with carbon-14 in water samples collected from the Mayfield area, southwestern Idaho, 2011-12.

Nutrient data plotted with carbon-14 values indicate modern, higher-nutrient water is recharging the perched aquifer, whereas older, lower-nutrient water generally predominates in the deep aquifer (fig. 4). Recent recharge with higher concentrations of nutrients may not have reached the deep aquifer system at the time of sampling.

Naturally occurring metals and trace elements can be derived from aquifer material and transported in groundwater. Concentrations of metals and trace elements were variable in water samples collected from the study area (table 6). Higher concentrations of aluminum, beryllium, cobalt, copper, lead, iron, manganese, and nickel were measured in the Indian Creek surface-water sample than in the groundwater samples. Water from the deep aquifer generally had higher concentrations of lithium, molybdenum, and tungsten than water in the perched aquifer. Several deep aquifer wells and the mountain system well samples contained more elevated concentrations of some trace elements than the perched aquifer, such as lithium and arsenic (fig. 5), suggesting that sediment from the Danskin Mountains influences chemistry in the deep aquifer. SPF Engineering (2007b) also noted increasing arsenic concentrations with depth. Metals and trace elements did not show a consistent change in concentration along a relative flow path; some metals increased in concentration along the flow path, while others decreased or deviated from the trend at a given well (fig. 5).

The ratios of oxygen-18 and deuterium (hydrogen-2) in precipitation vary in response to the source of the precipitation, season, altitude, temperature, amount of evaporation, and other factors such as mixing of water from different sources. Thus, oxygen- 18 and deuterium can provide information regarding the seasonality and altitude of the precipitation that recharged the groundwater. The ratios of oxygen-18 and deuterium to their lighter isotopes (also known as the signature) can indicate sources of recharge water and changes to water since precipitation, such as evaporation or water-rock interaction (Coplen, 1993). Meteoric water lines, such as the Global Meteoric Water Line (GMWL; Craig, 1961) or a Local Meteoric Water Line (LMWL), are used to describe a continuum in the isotopic signature of the precipitation. For this study, three meteoric water lines were plotted with data: the GMWL $\left(\delta^{2} \mathrm{H}=8 \times \delta^{18} \mathrm{O}+10\right)$, a LMWL developed by Schlegel and others (2009) for the Boise area $\left(\delta^{2} \mathrm{H}=6.94 \times \delta^{18} \mathrm{O}-10.7\right)$, and a LMWL developed by Wood and Low (1988) for the SRP area $\left(\delta^{2} \mathrm{H}=6.4 \times \delta^{18} \mathrm{O}-21\right)$. 
Table 6. Metals and trace-element concentrations for water samples collected in the Mayfield area, southwestern Idaho, 2011-12.

[Abbreviations LT-MDL, long term-method detection limit; $\mu \mathrm{g} / \mathrm{L}$, microgram per liter; $<$, less than]

\begin{tabular}{|c|c|c|c|c|c|c|c|c|}
\hline $\begin{array}{c}\text { Unique } \\
\text { station } \\
\text { identifier }\end{array}$ & $\begin{array}{c}\text { Aluminum, } \\
\text { water, } \\
\text { filtered } \\
(\mu \mathrm{g} / \mathrm{L})\end{array}$ & $\begin{array}{c}\text { Antimony, } \\
\text { water, } \\
\text { filtered } \\
(\mu \mathrm{g} / \mathrm{L})\end{array}$ & $\begin{array}{c}\text { Arsenic, } \\
\text { water, } \\
\text { filtered } \\
(\mu \mathrm{g} / \mathrm{L})\end{array}$ & $\begin{array}{c}\text { Barium, } \\
\text { water, } \\
\text { filtered } \\
(\mu \mathrm{g} / \mathrm{L})\end{array}$ & $\begin{array}{c}\text { Beryllium, } \\
\text { water, } \\
\text { filtered } \\
(\mu \mathrm{g} / \mathrm{L})\end{array}$ & $\begin{array}{c}\text { Boron, } \\
\text { water, } \\
\text { filtered } \\
(\mu \mathrm{g} / \mathrm{L})\end{array}$ & $\begin{array}{c}\text { Cadmium, } \\
\text { water, } \\
\text { filtered } \\
(\mu \mathrm{g} / \mathrm{L})\end{array}$ & $\begin{array}{c}\text { Chromium, } \\
\text { water, } \\
\text { filtered } \\
\text { ( } \mu \mathrm{g} / \mathrm{L})\end{array}$ \\
\hline LT-MDL & 2.2 & 0.027 & 0.03 & 0.07 & 0.006 & 3 & 0.016 & 0.070 \\
\hline \multicolumn{9}{|c|}{ Perched aquifer near Indian Creek Reservoir } \\
\hline PICR1 & $<1.7$ & 0.057 & 2.9 & 280 & $<0.006$ & 56 & $<0.016$ & 0.25 \\
\hline \multicolumn{9}{|c|}{ Mountain system } \\
\hline M1 & $<1.7$ & 0.057 & 7.5 & 8.2 & 0.008 & 19 & $<0.016$ & 0.21 \\
\hline \multicolumn{9}{|c|}{ Perched aquifer } \\
\hline $\mathrm{P} 1$ & 20.7 & 0.087 & 3.2 & 42 & $<0.006$ & 25 & $<0.016$ & 1.2 \\
\hline $\mathrm{P} 2$ & $<1.7$ & 0.050 & 3.5 & 47 & 0.009 & 21 & $<0.016$ & 0.16 \\
\hline P3 & $<1.7$ & 0.049 & 1.8 & 49 & $<0.006$ & 15 & $<0.016$ & 0.53 \\
\hline P4 & $<1.7$ & 0.060 & 2.3 & 51 & 0.009 & 22 & $<0.016$ & 0.34 \\
\hline P5 & $<1.7$ & 0.056 & 2.4 & 45 & $<0.006$ & 17 & $<0.016$ & 0.68 \\
\hline \multicolumn{9}{|c|}{ Deep aquifer } \\
\hline D1 & $<1.7$ & 0.042 & 2.8 & 4.0 & $<0.006$ & 15 & $<0.016$ & 0.88 \\
\hline D2 & 14.6 & 0.074 & 5.5 & 5.6 & $<0.006$ & 14 & $<0.016$ & 0.28 \\
\hline D3 & $<1.7$ & 0.028 & 5.8 & 15 & $<0.006$ & 12 & $<0.016$ & 1.2 \\
\hline D4 & $<1.7$ & 0.029 & 2.5 & 4.6 & $<0.006$ & 18 & $<0.016$ & 0.38 \\
\hline D5 & 5.8 & 0.036 & 2.9 & 42 & $<0.006$ & 18 & $<0.016$ & 1.5 \\
\hline D6 & 2.2 & 0.027 & 6.8 & 15 & $<0.006$ & 46 & $<0.016$ & 9.9 \\
\hline D7 & 2.2 & 0.035 & 6.9 & 36 & $<0.006$ & 15 & $<0.016$ & 1.5 \\
\hline \multicolumn{9}{|c|}{ Surface water } \\
\hline SW1 & 350 & 0.11 & 1.6 & 18 & 0.04 & 15 & $<0.016$ & 0.25 \\
\hline \multicolumn{9}{|c|}{ Replicate samples } \\
\hline M1R & $<1.7$ & 0.049 & 7.5 & 8.2 & 0.013 & 19 & $<0.016$ & 0.20 \\
\hline D7R & 2.2 & 0.036 & 6.9 & 36 & $<0.006$ & 14 & $<0.016$ & 1.4 \\
\hline
\end{tabular}


Table 6. Metals and trace-element concentrations for water samples collected in the Mayfield area, southwestern Idaho, 2011-12.-Continued

[Abbreviations LT-MDL, long term-method detection limit; $\mu \mathrm{g} / \mathrm{L}$, microgram per liter; <, less than]

\begin{tabular}{|c|c|c|c|c|c|c|c|c|}
\hline $\begin{array}{c}\text { Unique } \\
\text { station } \\
\text { identifier }\end{array}$ & $\begin{array}{c}\text { Cobalt, } \\
\text { water, } \\
\text { filtered } \\
(\mu \mathrm{g} / \mathrm{L})\end{array}$ & $\begin{array}{l}\text { Copper, } \\
\text { water, } \\
\text { filtered } \\
(\mu \mathrm{g} / \mathrm{L})\end{array}$ & $\begin{array}{c}\text { Iron, } \\
\text { water, } \\
\text { filtered } \\
(\mu \mathrm{g} / \mathrm{L})\end{array}$ & $\begin{array}{r}\text { Lead, } \\
\text { water, } \\
\text { filtered } \\
(\mu \mathrm{g} / \mathrm{L})\end{array}$ & $\begin{array}{c}\text { Lithium, } \\
\text { water, } \\
\text { filtered } \\
(\mu \mathrm{g} / \mathrm{L})\end{array}$ & $\begin{array}{c}\text { Manganese, } \\
\text { water, } \\
\text { filtered } \\
(\mu \mathrm{g} / \mathrm{L})\end{array}$ & $\begin{array}{c}\text { Molybdenum, } \\
\text { water, } \\
\text { filtered } \\
(\mu \mathrm{g} / \mathrm{L})\end{array}$ & $\begin{array}{c}\text { Nickel, } \\
\text { water, } \\
\text { filtered } \\
(\mu \mathrm{g} / \mathrm{L})\end{array}$ \\
\hline LT-MDL & 0.021 & 0.80 & 3.2 & 0.025 & 0.22 & 0.13 & 0.014 & 0.09 \\
\hline \multicolumn{9}{|c|}{ Perched aquifer near Indian Creek Reservoir } \\
\hline PICR1 & 0.35 & 0.88 & $<3.2$ & 0.16 & 16 & 0.27 & 0.57 & 7.2 \\
\hline \multicolumn{9}{|c|}{ Mountain system } \\
\hline M1 & 0.026 & 1.9 & $<3.2$ & 0.087 & 7.7 & 0.31 & 0.34 & $<0.09$ \\
\hline \multicolumn{9}{|c|}{ Perched aquifer } \\
\hline $\mathrm{P} 1$ & 0.12 & $<0.80$ & 20 & $<0.025$ & 18 & 0.53 & 1.04 & 1.4 \\
\hline $\mathrm{P} 2$ & $<0.020$ & $<0.50$ & 28 & $<0.025$ & 4.8 & 3.51 & 1.0 & 0.3 \\
\hline P3 & 0.024 & 0.51 & 22 & 2.5 & 4.0 & 3.77 & 1.9 & 0.13 \\
\hline $\mathrm{P} 4$ & 0.031 & 1.1 & $<3.2$ & 0.10 & 7.4 & 0.83 & 0.90 & 0.22 \\
\hline P5 & $<0.020$ & $<0.50$ & $<3.2$ & 0.075 & 4.7 & $<0.13$ & 0.81 & 0.09 \\
\hline \multicolumn{9}{|c|}{ Deep aquifer } \\
\hline D1 & $<0.020$ & $<0.50$ & 14 & 0.025 & 12 & 1.23 & 1.5 & 0.12 \\
\hline D2 & 0.15 & $<0.80$ & 7.2 & 0.052 & 17 & 18 & 2.6 & 0.37 \\
\hline D3 & 0.021 & $<0.50$ & $<3.2$ & 0.018 & 14 & 0.19 & 1.2 & $<0.090$ \\
\hline D4 & $<0.020$ & 1.1 & 6.8 & 0.41 & 16 & 0.16 & 1.5 & $<0.090$ \\
\hline D5 & 0.14 & $<0.8$ & 49 & 0.34 & 9.2 & 8.12 & 1.7 & 0.24 \\
\hline D6 & $<0.021$ & $<0.8$ & 4.3 & 0.026 & 11 & 0.66 & 3.1 & $<0.090$ \\
\hline D7 & $<0.021$ & 6.1 & $<3.2$ & 0.092 & 14 & 0.17 & 1.6 & 0.20 \\
\hline \multicolumn{9}{|c|}{ Surface water } \\
\hline SW1 & 3.3 & 2.5 & 498 & 1.48 & 16.7 & 34.3 & 0.64 & 0.87 \\
\hline \multicolumn{9}{|c|}{ Replicate samples } \\
\hline M1R & $<0.020$ & 1.8 & $<3.2$ & 0.085 & 7.7 & 0.30 & 0.35 & 0.090 \\
\hline D7R & $<0.021$ & 3.2 & $<3.2$ & 0.091 & 12 & 0.18 & 1.7 & 0.19 \\
\hline
\end{tabular}


Table 6. Metals and trace-element concentrations for water samples collected in the Mayfield area, southwestern Idaho, 2011-12.-Continued

[Abbreviations LT-MDL, long term-method detection limit; $\mu \mathrm{g} / \mathrm{L}$, microgram per liter; $<$, less than]

\begin{tabular}{|c|c|c|c|c|c|c|c|c|c|}
\hline $\begin{array}{l}\text { Unique } \\
\text { station } \\
\text { identifier }\end{array}$ & $\begin{array}{c}\text { Selenium, } \\
\text { water, } \\
\text { filtered } \\
(\mu \mathrm{g} / \mathrm{L})\end{array}$ & $\begin{array}{c}\text { Silica, } \\
\text { water, } \\
\text { filtered } \\
(\mu \mathrm{g} / \mathrm{L} \text { as } \\
\left.\mathrm{SiO}_{2}\right)\end{array}$ & $\begin{array}{c}\text { Silver, } \\
\text { water, } \\
\text { filtered } \\
(\mu \mathrm{g} / \mathrm{L})\end{array}$ & $\begin{array}{c}\text { Strontium, } \\
\text { water, } \\
\text { filtered } \\
(\mu \mathrm{g} / \mathrm{L})\end{array}$ & $\begin{array}{l}\text { Thallium, } \\
\text { water, } \\
\text { filtered } \\
\text { ( } \mu \mathrm{g} / \mathrm{L})\end{array}$ & $\begin{array}{c}\text { Tungsten, } \\
\text { water, } \\
\text { filtered } \\
\text { ( } \mu \mathrm{g} / \mathrm{L})\end{array}$ & $\begin{array}{c}\text { Vanadium, } \\
\text { water, } \\
\text { filtered } \\
\text { ( } \mu \mathrm{g} / \mathrm{L})\end{array}$ & $\begin{array}{c}\text { Uranium } \\
\text { (natural), } \\
\text { water, } \\
\text { filtered } \\
\text { ( } \mu \mathrm{g} / \mathrm{L})\end{array}$ & $\begin{array}{r}\text { Zinc, } \\
\text { water, } \\
\text { filtered } \\
(\mu \mathrm{g} / \mathrm{L})\end{array}$ \\
\hline LT-MDL & 0.030 & 0.060 & 0.005 & 0.200 & 0.01 & 0.010 & 0.080 & 0.0040 & 1.4 \\
\hline \multicolumn{10}{|c|}{ Perched aquifer near Indian Creek Reservoir } \\
\hline PICR1 & 0.77 & 48 & $<0.005$ & 743 & $<0.01$ & 0.018 & 9.0 & 27 & 18 \\
\hline \multicolumn{10}{|c|}{ Mountain system } \\
\hline M1 & 0.14 & 43 & $<0.005$ & 133 & $<0.01$ & $<0.010$ & 2.6 & 0.49 & 9.0 \\
\hline \multicolumn{10}{|c|}{ Perched aquifer } \\
\hline $\mathrm{P} 1$ & 1.0 & 44 & $<0.005$ & 159 & $<0.01$ & 0.027 & 4.9 & 0.12 & 2.8 \\
\hline $\mathrm{P} 2$ & 0.050 & 53 & $<0.005$ & 142 & $<0.01$ & $<0.010$ & 4.2 & 0.34 & 5.7 \\
\hline P3 & 0.21 & 47 & $<0.005$ & 134 & $<0.01$ & $<0.010$ & 6.7 & 0.36 & 140 \\
\hline $\mathrm{P} 4$ & 0.54 & 39 & $<0.005$ & 173 & $<0.01$ & 0.016 & 4.5 & 0.66 & $<1.4$ \\
\hline P5 & 0.34 & 50 & $<0.005$ & 129 & $<0.01$ & $<0.010$ & 6.1 & 0.47 & 9.7 \\
\hline \multicolumn{10}{|c|}{ Deep aquifer } \\
\hline D1 & 1.0 & 54 & $<0.005$ & 106 & $<0.01$ & $<0.010$ & 2.1 & 0.26 & 190 \\
\hline D2 & 0.22 & 47 & $<0.005$ & 82.1 & $<0.01$ & 0.14 & 2.0 & 0.33 & 3.6 \\
\hline D3 & 0.52 & 46 & $<0.005$ & 103 & $<0.01$ & 0.013 & 2.5 & 0.29 & 1.8 \\
\hline D4 & 0.11 & 35 & $<0.005$ & 95.5 & $<0.01$ & 0.20 & 5.0 & 0.29 & 18 \\
\hline D5 & 0.47 & 42 & $<0.005$ & 160 & $<0.01$ & 0.24 & 4.7 & 2.9 & 80 \\
\hline D6 & 0.36 & 63 & $<0.005$ & 66.6 & $<0.01$ & 0.82 & 35 & 0.57 & 23 \\
\hline D7 & 0.41 & 48 & $<0.005$ & 140 & $<0.01$ & 0.096 & 6.1 & 1.1 & 6.0 \\
\hline \multicolumn{10}{|c|}{ Surface water } \\
\hline SW1 & 0.070 & 30 & $<0.005$ & 53.8 & $<0.01$ & 0.011 & 2.4 & 0.37 & 5.3 \\
\hline \multicolumn{10}{|c|}{ Replicate samples } \\
\hline M1R & 0.13 & 42 & $<0.005$ & 132 & $<0.01$ & $<0.010$ & 2.6 & 0.49 & 9.2 \\
\hline D7R & 0.41 & 48 & $<0.005$ & 141 & $<0.01$ & 0.097 & 6 & 1.1 & 5.9 \\
\hline
\end{tabular}




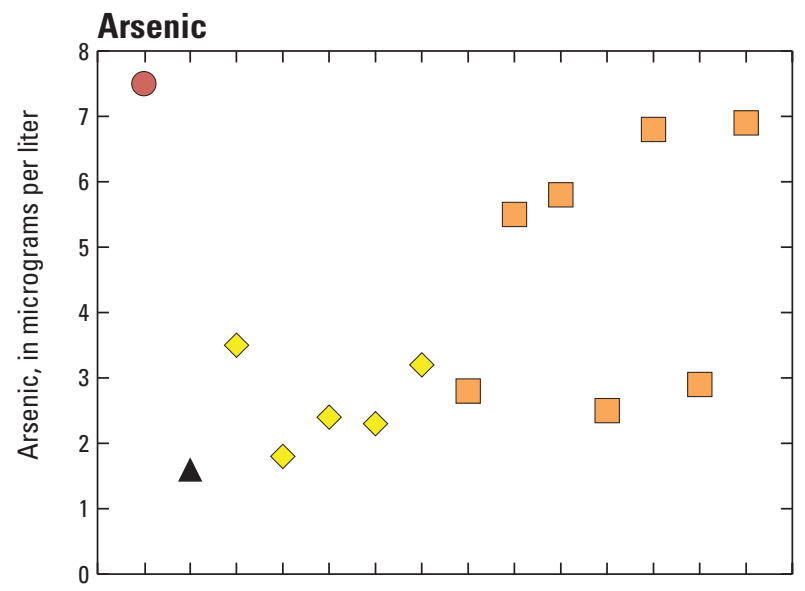

EXPLANATION

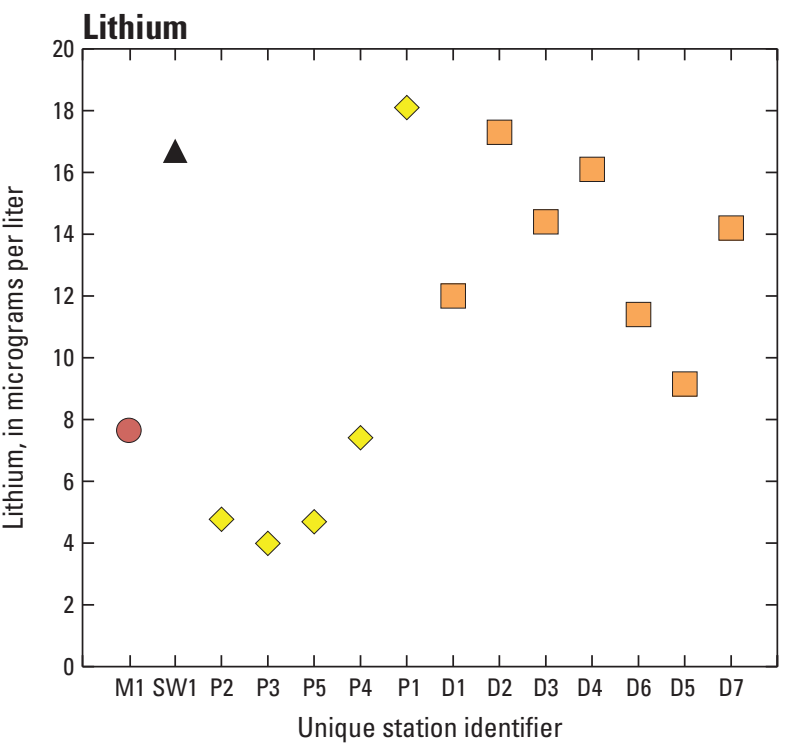

Mountain system

$\diamond \quad$ Perched aquifer

$\square \quad$ Deep aquifer

$\Delta \quad$ Indian Creek

Figure 5. Concentrations of arsenic and lithium along a relative flow path in water samples collected from wells from the Mayfield area, southwestern Idaho, 2011-12. 
The stable isotope ratios in water samples (table 7) were plotted on a delta diagram (fig. 6) with the GMWL and the two LMWLs, as well as the mean stable isotope values from geothermal waters in Idaho (Parliman and Young, 1992). The most negative (depleted) ratio was from the Indian Creek sample collected during winter. Samples from the perched aquifers tended to be more enriched (less negative ratios) than water from the deep aquifer. All samples collected during this study were more enriched than a data point representing mean geothermal water in Idaho, but still are within the range of stable isotopes exhibited by geothermal water (Parliman and Young, 1992). All water samples plot below the GMWL and LMWLs, but they still fall in a linear pattern, likely indicating that the study area may have its own meteoric water line different from the GMWL and the LMWLs. However, if the LMWLs actually represent local recharge, water samples that plot below and to the right of the LMWLs indicate enrichment of oxygen-18 as compared to deuterium. Preferential enrichment of oxygen-18 can be caused by evaporation (which generates a slope between 3 and 6 , less than the slope of data for this study) or water-rock interaction (which increases only the oxygen-18 signature) (Clark and Fritz, 1997). Based on geochemical modeling results, a large amount of water-rock interaction is probably not occurring; therefore, this pattern is likely caused by a different LMWL than what has been reported for nearby areas.

The most commonly used method of dating groundwater with an age of recharge between 1,000 and 40,000 years is carbon-14 (half-life of 5,370 years) dating. Carbon in groundwater is derived from various components of the carbon cycle, and carbon isotopes provide information about interactions between groundwater and its environment.

Table 7. Isotope data and corrected carbon-14 ages for water samples collected in the Mayfield area, southwestern Idaho, $2011-12$.

["Modern," indicates water recharged since the 1950s. Abbreviations: \%, per mil; $\delta^{2} \mathrm{H} \mathrm{H}_{2} \mathrm{O}$, hydrogen-2 in water; $\delta^{18} \mathrm{O} \mathrm{H}_{2} \mathrm{O}$, oxygen-18 in water; \%, per mil; $\delta^{13} \mathrm{C}$, carbon-13; pmc, percent modern carbon; $\varepsilon^{13} \mathrm{C}_{\mathrm{DIC}-\mathrm{CO} 2 \text { (soil) }}$, $\mathrm{pH}$ dependent enrichment factor; N/A, not applicable]

\begin{tabular}{|c|c|c|c|c|c|c|c|c|c|}
\hline $\begin{array}{l}\text { Unique } \\
\text { station } \\
\text { identifier }\end{array}$ & $\begin{array}{c}\delta^{2} H_{H_{2}} \mathbf{O} \\
(\%)\end{array}$ & $\begin{array}{c}\delta^{18} \mathrm{OH}_{2} \mathrm{O} \\
(\%)\end{array}$ & $\begin{array}{l}\delta^{13} \mathrm{C} \\
(\%)\end{array}$ & $\begin{array}{l}{ }^{14} \mathrm{C} \text { uncorrected } \\
(\mathrm{pmc})\end{array}$ & $\begin{array}{l}{ }^{14} \mathrm{C} \text { error } \\
\text { (pmc) }\end{array}$ & $\begin{array}{c}\text { pH enrichment } \\
\text { factor } \\
\left(\varepsilon^{13} C_{\text {DIC-CO }_{2} \text { (soil) }}\right)\end{array}$ & $\begin{array}{l}\text { Dilution } \\
\text { factor }\end{array}$ & $\begin{array}{c}\text { Uncorrected age } \\
\text { (years) }\end{array}$ & $\begin{array}{c}\text { Corrected } \\
\text { age } \\
\text { (years) }\end{array}$ \\
\hline PICR1 & -116.99 & -14.72 & -15.38 & 93.54 & 0.28 & 18.3 & -0.84 & 552 & Modern \\
\hline $\mathrm{P} 1$ & -121.04 & -15.30 & -16.42 & 104.40 & 0.40 & -11 & 1.5 & Modern & Modern \\
\hline P2 & -124.85 & -15.68 & -16.46 & 90.40 & 0.31 & -9.7 & 1.7 & 834 & 1,400 \\
\hline P3 & -124.38 & -15.43 & -15.15 & 93.76 & 0.29 & -11 & 1.3 & 533 & 710 \\
\hline P4 & -120.55 & -15.16 & -15.53 & 111.30 & 0.44 & -12 & 1.4 & Modern & Modern \\
\hline D2 & -125.36 & -15.93 & -15.37 & 74.51 & 0.23 & -7.7 & 1.2 & 2,432 & 2,900 \\
\hline D3 & -126.10 & -16.02 & -14.01 & 67.88 & 0.24 & -9.3 & 0.98 & 3,203 & 3,100 \\
\hline D4 & -124.76 & -15.61 & -12.96 & 40.07 & 0.15 & -4.7 & 1.3 & 7,561 & 10,000 \\
\hline D5 & -127.02 & -16.10 & -13.34 & 55.34 & 0.17 & -4.8 & 1.4 & 4,891 & 6,700 \\
\hline D6 & -132.01 & -16.68 & -11.94 & 32.56 & 0.13 & -6.8 & 1.0 & 9,276 & 9,400 \\
\hline D7 & -125.74 & -15.84 & -14.13 & 54.77 & 0.18 & -5.3 & 1.4 & 4,977 & 6,800 \\
\hline SW1 & -133.37 & -17.22 & N/A & N/A & N/A & N/A & N/A & N/A & N/A \\
\hline M1R & -121.12 & -15.21 & -17.25 & 101.56 & 0.33 & N/A & N/A & N/A & N/A \\
\hline
\end{tabular}




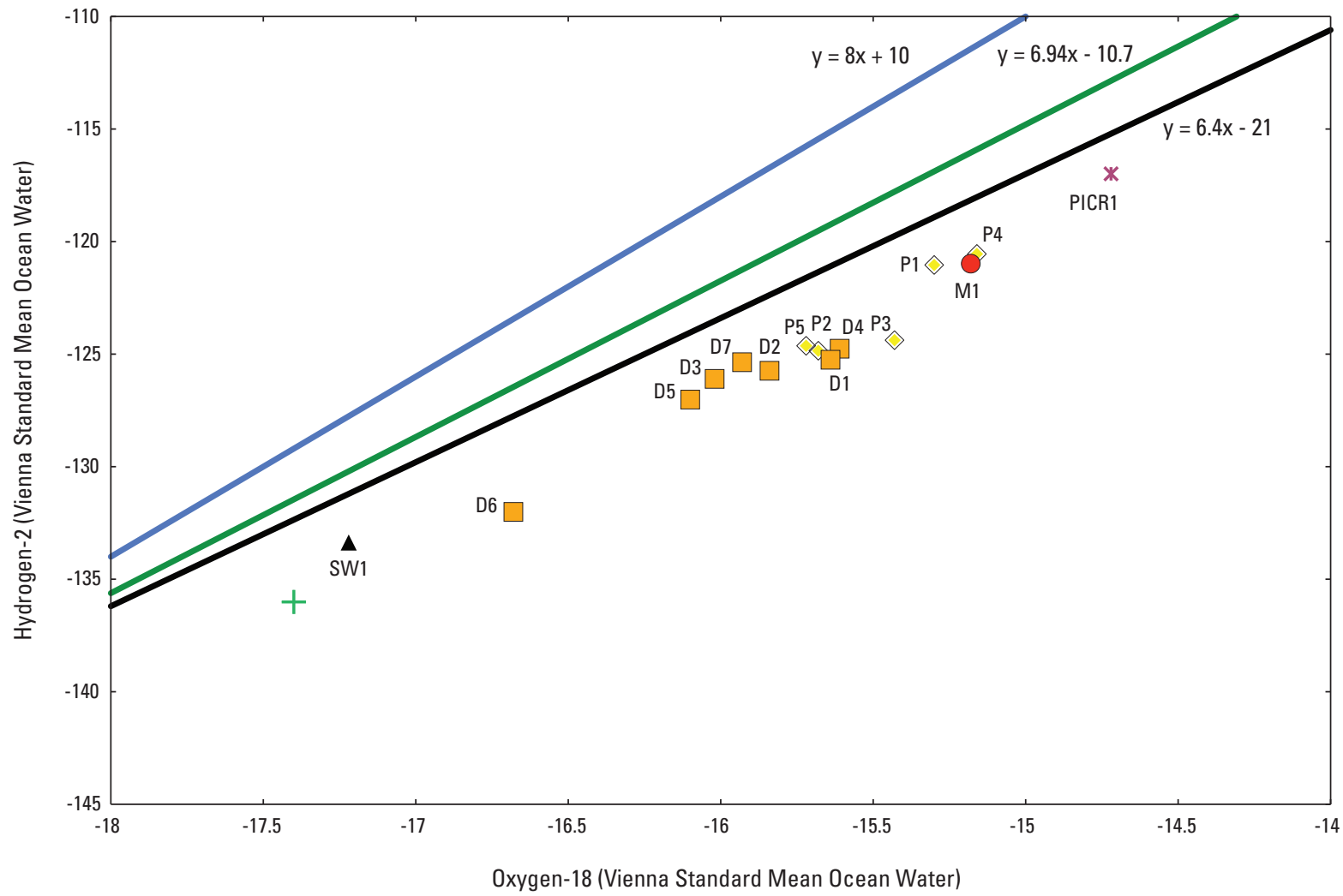

\section{EXPLANATION}

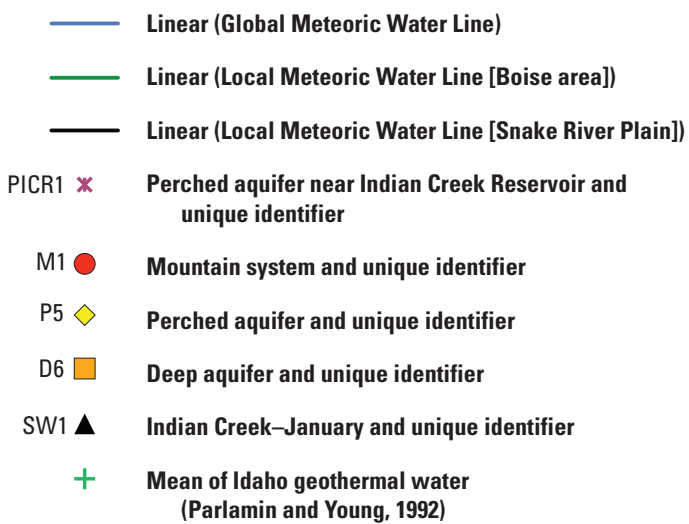

Figure 6. Oxygen and hydrogen isotopes from groundwater and surface water in the Mayfield area, southwestern Idaho, 2011-12, plotted with a global meteoric water line (GMWL) and two local meteoric water lines (LMWLs). 
Most of the carbon-14 measured in groundwater is derived from carbon dioxide or inorganic carbon present in the soil zone during recharge that dissolves into water as it moves through the saturated zone. As water moves along a flow path, carbon-14 can be diluted, necessitating correction techniques that can range from simple mathematical calculations to complex geochemical modeling. For this study, an open-system carbon-13 mixing model was applied to evaluate whether significant carbonate dissolution occurred along the flow path (Coplen, 1993; Clark and Fritz, 1997). Estimated carbon-13 values were used in this model and corrected ages contain a large amount of uncertainty.

Carbon-13 ratios, carbon-14 results, and interpretations of age dating are presented in table 7. Carbon-13 ratios were most depleted (negative) in the mountain system and in the upgradient part of the deep and perched aquifers, and more enriched (less negative) farther down the flow path. Carbon-14 corrected ages in samples collected from the perched aquifer ranged from modern (less than 100 years old) to 1,400 years old; the sample from the mountain system also contained modern water. However, corrected carbon-14 ages in samples collected from the deep aquifer ranged from 2,700 to 10,000 years old. Carbon-14 age dates in the deep aquifer generally increased with depth and distance along a flow path, indicating that the conceptual flow path in the deep aquifer is reasonable. Age dates in the perched aquifer tended to increase with depth but not with distance from the mountain front, perhaps suggesting that the perched aquifer is discontinuous.

Dissolved gases were used to determine the recharge temperature and to calibrate CFC models. Separate analyses were performed for each sample for quality-control purposes (table 8). Estimated recharge temperatures ranged from 5.7 to $18.9^{\circ} \mathrm{C}$, and are reported based on recharge $500 \mathrm{ft}$ above the land-surface at the well (table 8) and were used in CFC calculations.

Chlorofluorocarbons are stable volatile organic compounds (VOCs) that were introduced to the atmosphere beginning in the 1930s during production of refrigerants, cleaning solvents, foams, plastic, and other synthetic materials (Clark and Fritz, 1997). CFCs released into the atmosphere are stable; historical atmospheric concentrations of CFCs are known. Measuring ratios of CFC-12

(dichlorodifluoromethane), CFC-11 (trichlorofluoromethane), and CFC-113 (trichlorotrifluorethane) in groundwater enables identification of the age of groundwater recharged since about 1941, 1947, and 1955, respectively. Laboratory results include the amount of CFCs in a given sample, a modeled recharge date, and the amount of young water as determined by CFCs in a sample.

CFCs were found in samples from every well in the study area, indicating all groundwater samples contained some modern recharge (table 9). Modeled recharge dates ranged from the late 1940s to the late 1980s. Recharge dates for samples in the perched aquifer ranged from the late 1940s to the mid-1980s, whereas samples in the deep aquifer ranged from the late 1940s to the mid-1970s. Samples did not show a systematic pattern in recharge date along a flow path. CFC results also included an estimate of the amount of young water (water dateable by CFCs) in each sample by ratio dating (table 9). Samples in the Mayfield area contained between 1 and 94 percent young water, with the smallest percentage of young water in P2 (between 1 and 6 percent young water) and D2 (between 2 and 7 percent young water) (fig. 7).

The age tracers used in this study (carbon-14 and CFCs) produced different recharge dates for the same sample of water. Carbon-14 dates indicated that groundwater ages ranged from modern to thousands of years; all samples from the deep aquifer had mean residence times of more than 2,000 years. Modern recharge (indicated by the presence of CFCs) was present in every water sample collected from wells, including those wells with older water dated by carbon-14. Older water could be a product of depth, distance from the recharge zone, or isolation due to a local confining unit; however, the presence of CFCs in water with an older mean residence time indicates that some modern recharge is making its way to the deeper part of the aquifer. The presence of both young and old water suggests that the study area contains mixed groundwater, or that groundwater is not moving as piston flow, a basic assumption used in the computation of CFC-derived recharge dates.

Geochemical modeling results refine concepts of flow paths and sources of recharge. Model simulation results can be confirmed by calculated saturation indices for individual samples (table 10). Mineral phases that were included in models were constrained by mineral reactions along the flow path; successful models showed the dissolution of biotite, calcite, $\mathrm{CO}_{2}$ gas, fluorite, plagioclase, potassium feldspar, and pyrite and the precipitation of calcium montmorollionite, ferric hydroxide, and $\mathrm{SiO}_{2}$ (table 11). Many attempted flow paths were considered invalid because they showed precipitation of $\mathrm{CO}_{2}$ gas, an unlikely reaction in this area. 
Table 8. Dissolved gas data and estimated recharge temperatures for water samples collected in the Mayfield area, southwestern Idaho, 2011-12.

[Samples analyzed in duplicate. Abbreviations: $\mathrm{N}_{2}$, nitrogen gas; Ar, argon gas; $\mathrm{O}_{2}$ oxygen gas; $\mathrm{CO}_{2}$, carbon dioxide gas; $\mathrm{CH}_{4}$, methane gas; $\mathrm{mg} / \mathrm{L}$, milligram per liter; $\mathrm{ft}$, foot; ${ }^{\circ} \mathrm{C}$, degrees Celsius; cc STP/L, cubic centimeters per liter of pressure at standard temperature and pressure]

\begin{tabular}{|c|c|c|c|c|c|c|c|c|}
\hline $\begin{array}{c}\text { Unique } \\
\text { station } \\
\text { identifier }\end{array}$ & $\begin{array}{c}\mathrm{N}_{2} \\
(\mathrm{mg} / \mathrm{L})\end{array}$ & $\underset{(\mathrm{mg} / \mathrm{L})}{\mathrm{Ar}}$ & $\begin{array}{c}\mathrm{O}_{2} \\
(\mathrm{mg} / \mathrm{L})\end{array}$ & $\begin{array}{c}\mathrm{CO}_{2} \\
(\mathrm{mg} / \mathrm{L})\end{array}$ & $\underset{(\mathrm{mg} / \mathrm{L})}{\mathrm{CH}_{4}}$ & $\begin{array}{c}\text { Assigned } \\
\text { recharge } \\
\text { altitude } \\
\text { (ft) }\end{array}$ & $\begin{array}{l}\text { Recommended } \\
\text { recharge } \\
\text { temperature } \\
\left({ }^{\circ} \mathrm{C}\right)\end{array}$ & $\begin{array}{l}\text { Excess air } \\
\text { (cc STP/L) }\end{array}$ \\
\hline PICR1 & 19.7967 & 0.6816 & 4.9022 & 42.0630 & 0.00000 & 3,859 & 8.09 & 3.49 \\
\hline PICR1 & 19.5972 & 0.6774 & 4.9443 & 42.1243 & 0.00000 & 3,859 & 8.19 & 3.32 \\
\hline M1 & 20.0588 & 0.6846 & 1.7664 & 32.8804 & 0.00000 & 4,261 & 7.68 & 3.85 \\
\hline M1 & 20.0297 & 0.6834 & 1.7996 & 32.7183 & 0.00000 & 4,261 & 7.76 & 3.85 \\
\hline P1 & 19.5594 & 0.6987 & 4.1333 & 29.3521 & 0.00000 & 3,929 & 5.71 & 2.34 \\
\hline $\mathrm{P} 1$ & 19.3694 & 0.6926 & 3.8675 & 27.9613 & 0.00000 & 3,929 & 6.01 & 2.27 \\
\hline $\mathrm{P} 2$ & 20.0106 & 0.6758 & 0.4896 & 34.5638 & 0.00000 & 4,082 & 8.87 & 4.14 \\
\hline $\mathrm{P} 2$ & 19.8813 & 0.6721 & 0.4489 & 34.7401 & 0.00000 & 4,082 & 9.04 & 4.07 \\
\hline P3 & 19.8028 & 0.6654 & 5.5482 & 25.6374 & 0.00092 & 4,071 & 9.71 & 4.22 \\
\hline P3 & 19.5926 & 0.6613 & 5.6115 & 25.5677 & 0.00088 & 4,071 & 9.76 & 4.02 \\
\hline P4 & 18.6033 & 0.6786 & 5.3373 & 30.4024 & 0.00000 & 4,017 & 5.99 & 1.54 \\
\hline P4 & 18.5319 & 0.6756 & 5.2976 & 30.2968 & 0.00000 & 4,017 & 6.18 & 1.54 \\
\hline P5 & 15.5559 & 0.5873 & 6.9866 & 15.7585 & 0.00000 & 4,030 & 10.5 & 0.12 \\
\hline P5 & 15.3666 & 0.5856 & 6.6045 & 16.4499 & 0.00000 & 4,030 & 10.3 & -0.14 \\
\hline D1 & 17.4287 & 0.6224 & 2.2436 & 18.2853 & 0.00000 & 4,067 & 10.0 & 1.90 \\
\hline D1 & 17.3785 & 0.6213 & 2.3615 & 18.4592 & 0.00000 & 4,067 & 10.1 & 1.86 \\
\hline D2 & 16.8221 & 0.6172 & 0.2204 & 15.4252 & 0.00000 & 3,983 & 9.54 & 1.05 \\
\hline D2 & 16.7620 & 0.6140 & 0.2077 & 15.7818 & 0.00000 & 3,983 & 9.81 & 1.09 \\
\hline D3 & 14.3083 & 0.5360 & 5.2403 & 8.59014 & 0.00000 & 3,929 & 14.8 & 0.13 \\
\hline D3 & 14.4343 & 0.5398 & 5.0789 & 8.61414 & 0.00000 & 3,929 & 14.5 & 0.19 \\
\hline D4 & 14.5205 & 0.5193 & 3.8073 & 2.13068 & 0.00000 & 3,870 & 18.0 & 1.22 \\
\hline D4 & 14.3650 & 0.5147 & 3.6915 & 2.14732 & 0.00000 & 3,870 & 18.4 & 1.15 \\
\hline D5 & 14.7266 & 0.5170 & 2.9672 & 8.78133 & 0.00000 & 3,917 & 18.9 & 1.68 \\
\hline D5 & 14.8346 & 0.5189 & 2.5419 & 9.07804 & 0.00000 & 3,917 & 18.9 & 1.79 \\
\hline D6 & 16.9178 & 0.5890 & 4.0311 & 1.28358 & 0.00000 & 3,649 & 14.0 & 2.41 \\
\hline D6 & 16.8019 & 0.5864 & 4.0852 & 1.22602 & 0.00000 & 3,649 & 14.1 & 2.32 \\
\hline D7 & 13.5283 & 0.4994 & 1.3913 & 10.3746 & 0.00000 & 3,855 & 18.6 & 0.34 \\
\hline D7, & 13.5281 & 0.4984 & 2.2776 & 9.62868 & 0.00000 & 3,855 & 18.8 & 0.38 \\
\hline
\end{tabular}


Table 9. Chlorofluorocarbon results and simulated groundwater recharge dates based on recharge elevation for groundwater samples collected in the Mayfield area, southwestern Idaho, 2011-12.

[Samples analyzed in duplicate or triplicate. Sample identified by station name or well identifier. Abbreviations pmol/kg, picomole per kilogram; ${ }^{\circ} \mathrm{C}$, degrees Celsius; ft, foot; ERR, error; NP, not possible to determine]

\begin{tabular}{|c|c|c|c|c|c|c|c|c|c|c|c|}
\hline \multirow{2}{*}{$\begin{array}{c}\text { Unique } \\
\text { station } \\
\text { identifier }\end{array}$} & \multicolumn{3}{|c|}{$\begin{array}{l}\text { Corrected concentrations } \\
\qquad(\mathrm{pmol} / \mathrm{kg})\end{array}$} & \multirow{2}{*}{$\begin{array}{l}\text { Calculated } \\
\text { recharge } \\
\text { temperature } \\
\left({ }^{\circ} \mathrm{C}\right)\end{array}$} & \multirow{2}{*}{$\begin{array}{c}\text { Assumed } \\
\text { recharge } \\
\text { elevation } \\
\text { (ft) }\end{array}$} & \multirow{2}{*}{$\begin{array}{c}\text { Young } \\
\text { water in } \\
\text { sample } \\
\text { (percent) }\end{array}$} & \multicolumn{3}{|c|}{$\begin{array}{l}\text { Model piston dates } \\
\text { (excess air corrected) }\end{array}$} & \multirow{2}{*}{$\begin{array}{l}\text { Recommended } \\
\text { age based on }\end{array}$} & \multirow{2}{*}{$\begin{array}{l}\text { Young fraction } \\
\text { recharge date }\end{array}$} \\
\hline & CFC-11 & CFC-12 & CFC-113 & & & & CFC-11 & CFC-12 & CFC-113 & & \\
\hline \multicolumn{12}{|c|}{ Perched aquifer near Indian Creek Reservoir } \\
\hline PICR1 & 2.11 & 5.19 & 0.334 & 8.15 & 3,859 & $92-94$ & 1989 & 1985.5 & 1986.5 & CFC-11,12,113 & Mid to late1980s \\
\hline PICR1 & 2.15 & 4.96 & 0.342 & 8.15 & 3,859 & & 1987.5 & 1985.5 & 1986.5 & & \\
\hline PICR3 & 2.09 & 5.16 & 0.338 & 8.15 & 3,859 & & 1988.5 & 1985.5 & 1986.5 & & \\
\hline \multicolumn{12}{|c|}{ Mountain system } \\
\hline M1 & 0.915 & 1.09 & 0.144 & 7.6 & 4,261 & $20-52$ & 1969 & 1972 & 1979.5 & CFC-11,12 & Late 1960 s to early $1970 \mathrm{~s}$ \\
\hline M1 & 0.921 & 1.07 & 0.117 & 7.6 & 4,261 & & 1969 & 1972.5 & 1978 & & \\
\hline M1 & 0.908 & 1.12 & 0.105 & 7.6 & 4,261 & & 1969.5 & 1972 & 1977 & & \\
\hline \multicolumn{12}{|c|}{ Perched aquifer } \\
\hline P1 & 2.47 & 4.08 & 0.318 & 5.85 & 3,929 & $76-77$ & 1981 & 1986.5 & 1985 & CFC-12,113 & Mid 1980s \\
\hline P1 & 2.45 & 4.06 & 0.319 & 5.85 & 3,929 & & 1981 & 1986 & 1985 & NP & \\
\hline P2 & 0.0417 & 0.0733 & 0.008 & 8.95 & 4,082 & $1-6$ & 1955 & 1950.5 & 1959.5 & CFC-11,12,113 & Late 1940 s to early $1950 \mathrm{~s}$ \\
\hline P2 & 0.0312 & 0.0732 & 0.007 & 8.95 & 4,082 & & 1955 & 1949 & 1958.5 & & \\
\hline P2 & 0.0253 & 0.0682 & 0.011 & 8.95 & 4,082 & & 1954.5 & 1948 & 1961.5 & & \\
\hline P3 & 0.0473 & 0.100 & 0.006 & 9.75 & 4,071 & $3-17$ & 1956.5 & 1951 & 1958 & CFC-11,12,113 & Early to mid $1950 \mathrm{~s}$ \\
\hline P3 & 0.0655 & 0.100 & 0.007 & 9.75 & 4,071 & & 1956.5 & 1953 & 1959 & & \\
\hline P3 & 0.0603 & 0.111 & 0.008 & 9.75 & 4,071 & & 1956.5 & 1952.5 & 1960 & & \\
\hline P4 & 1.54 & 2.86 & 0.204 & 6.10 & 4,057 & $60-78$ & 1975.5 & 1977 & 1981.5 & CFC-11,12,113 & Mid to late 1970 s \\
\hline P4 & 1.55 & 2.87 & 0.205 & 6.10 & 4,057 & & 1975.5 & 1977 & 1981.5 & & \\
\hline P4 & 1.57 & 2.93 & 0.208 & 6.10 & 4,057 & & 1976 & 1978 & 1981.5 & & \\
\hline P5 & 1.03 & 1.50 & 0.158 & 10.4 & 4,030 & $34-57$ & 1972.5 & 1975 & 1982 & CFC-11,12 & Early to mid 1970 s \\
\hline P5 & 1.06 & 1.55 & 0.159 & 10.4 & 4,030 & & 1972.5 & 1975 & 1982 & & \\
\hline P5 & 1.05 & 1.52 & 0.156 & 10.4 & 4,030 & & 1972.5 & 1975 & 1981.5 & & \\
\hline \multicolumn{12}{|c|}{ Deep aquifer } \\
\hline D1 & 0.0192 & 0.0581 & 0.000 & 10.1 & 4,067 & NP & 1954.5 & 1947.5 & 1953 & CFC-11,12,113 & Late 1940 s to early $1950 \mathrm{~s}$ \\
\hline D1 & 0.0152 & 0.0782 & 0.000 & 10.1 & 4,067 & & 1955.5 & 1947 & 1953 & & \\
\hline D1 & 0.0192 & 0.0622 & 0.000 & 10.1 & 4,067 & & 1954.5 & 1947.5 & 1953 & & \\
\hline D2 & 0.0372 & 0.435 & 0.007 & 9.65 & 3,983 & $2-7$ & 1964 & 1950 & 1959 & CFC-12,113 & Early $1950 \mathrm{~s}$ \\
\hline D2 & 0.0392 & 0.169 & 0.006 & 9.65 & 3,983 & & 1959 & 1950.5 & 1958 & & \\
\hline D2 & 0.0414 & 0.531 & 0.006 & 9.65 & 3,983 & & 1965.5 & 1950.5 & 1958 & & \\
\hline D3 & 0.765 & 1.06 & 0.102 & 14.7 & 3,929 & $29-55$ & 1971.5 & 1974 & 1980 & CFC-11,12 & Early to mid 1970 s \\
\hline D3 & 0.791 & 1.08 & 0.116 & 14.7 & 3,929 & & 1971.5 & 1974 & 1981 & & \\
\hline D3 & 0.776 & 1.05 & 0.100 & 16.7 & 3,929 & & 1972 & 1975 & 1981 & & \\
\hline D4 & ERR & 0.809 & 0.082 & 18.2 & 3,870 & $26-56$ & 1971 & ERR & 1980 & CFC-11,12 & Early to mid 1970 s \\
\hline D4 & 0.630 & 0.808 & 0.073 & 18.2 & 3,870 & & 1971 & 1973.5 & 1979 & & \\
\hline D4 & 0.622 & 0.784 & 0.079 & 18.2 & 3,870 & & 1970.5 & 1973.5 & 1979.5 & & \\
\hline D5 & 0.135 & 0.198 & 0.045 & 19.0 & 3,862 & $46-69$ & 1962.5 & 1961.5 & 1975.5 & & Early $1960 \mathrm{~s}$ \\
\hline D5 & 0.138 & 0.192 & 0.042 & 19.0 & 3,862 & & 1962.5 & 1961.5 & 1975.5 & & \\
\hline D5 & 0.131 & 0.185 & 0.042 & 19.0 & 3,862 & & 1962 & 1961 & 1975.5 & & \\
\hline D6 & 0.374 & 0.388 & 0.053 & 14.1 & 3,649 & $22-23$ & 1965 & 1967.5 & 1975 & $\mathrm{CFC}, 11,12$ & Mid 1960s \\
\hline D6 & 0.338 & 0.355 & 0.042 & 14.1 & 3,649 & & 1964.5 & 1966.5 & 1973 & & \\
\hline D6 & 0.333 & 0.346 & 0.039 & 14.1 & 3,649 & 19-39 & 1964 & 1966.5 & 1972.5 & & \\
\hline D7 & 0.450 & 0.551 & 0.053 & 18.7 & 3,855 & & 1968.5 & 1970.5 & 1977 & CFC-11,12 & Late 1960 s to early $1970 \mathrm{~s}$ \\
\hline D7 & 0.448 & 0.548 & 0.054 & 18.7 & 3,855 & & 1968.5 & 1970.5 & 1977 & & \\
\hline
\end{tabular}




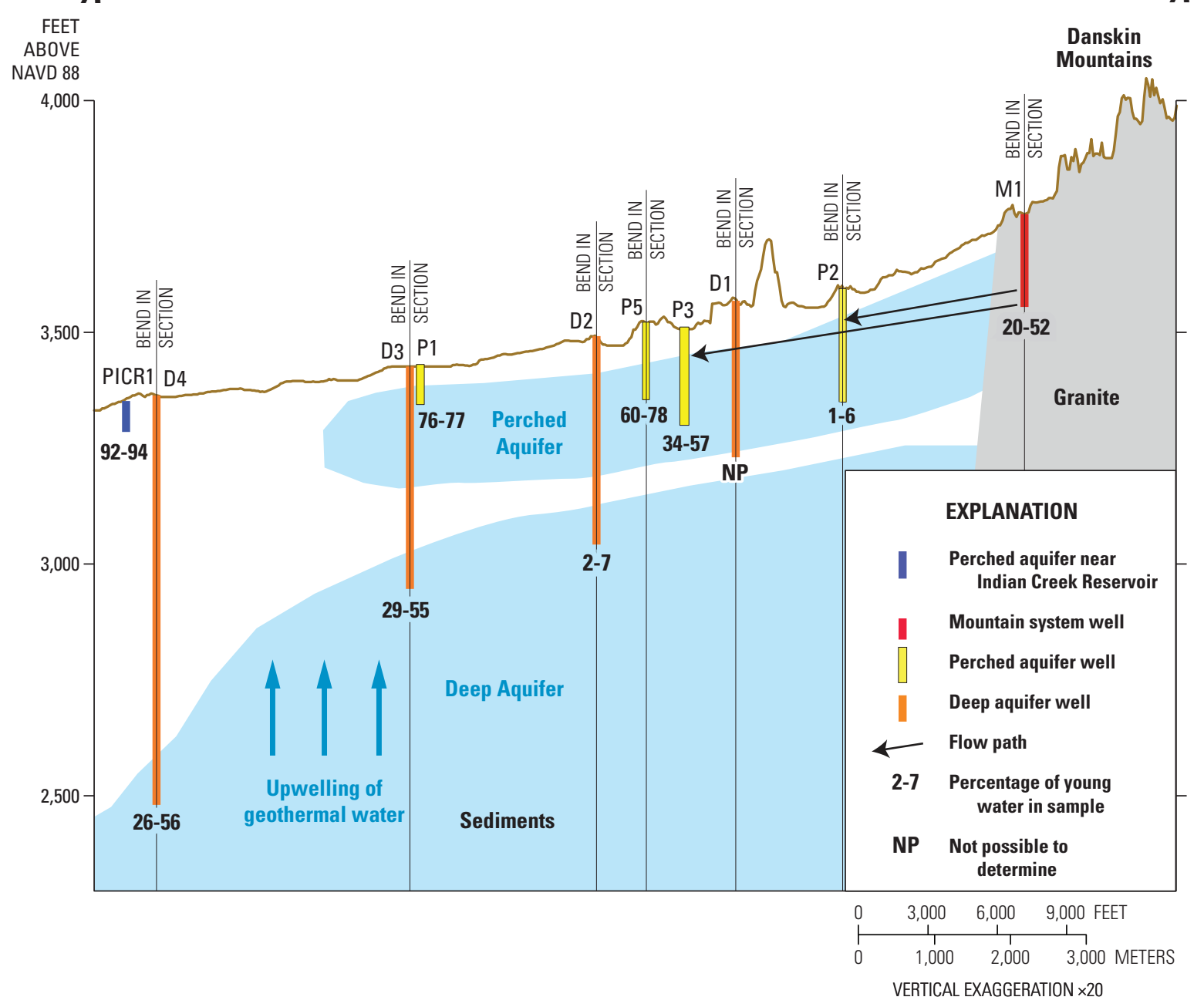

Figure 7. Selected wells and percentages of young water in samples collected in the Mayfield area, southwestern Idaho, 2011-12. 
Table 10. Saturation indices of selected water samples from wells in the Mayfield area, southwestern Idaho, $2011-12$.

[Positive saturation indices indicate the solution is oversaturated with respect to that mineral. Negative saturation indices indicate the solution is undersaturated with respect to that mineral. Saturation indices based on log K (equilibrium constant) values being set to zero. Only selected saturation indices are shown here. Saturation indices calculated from the WATEQ-4 database]

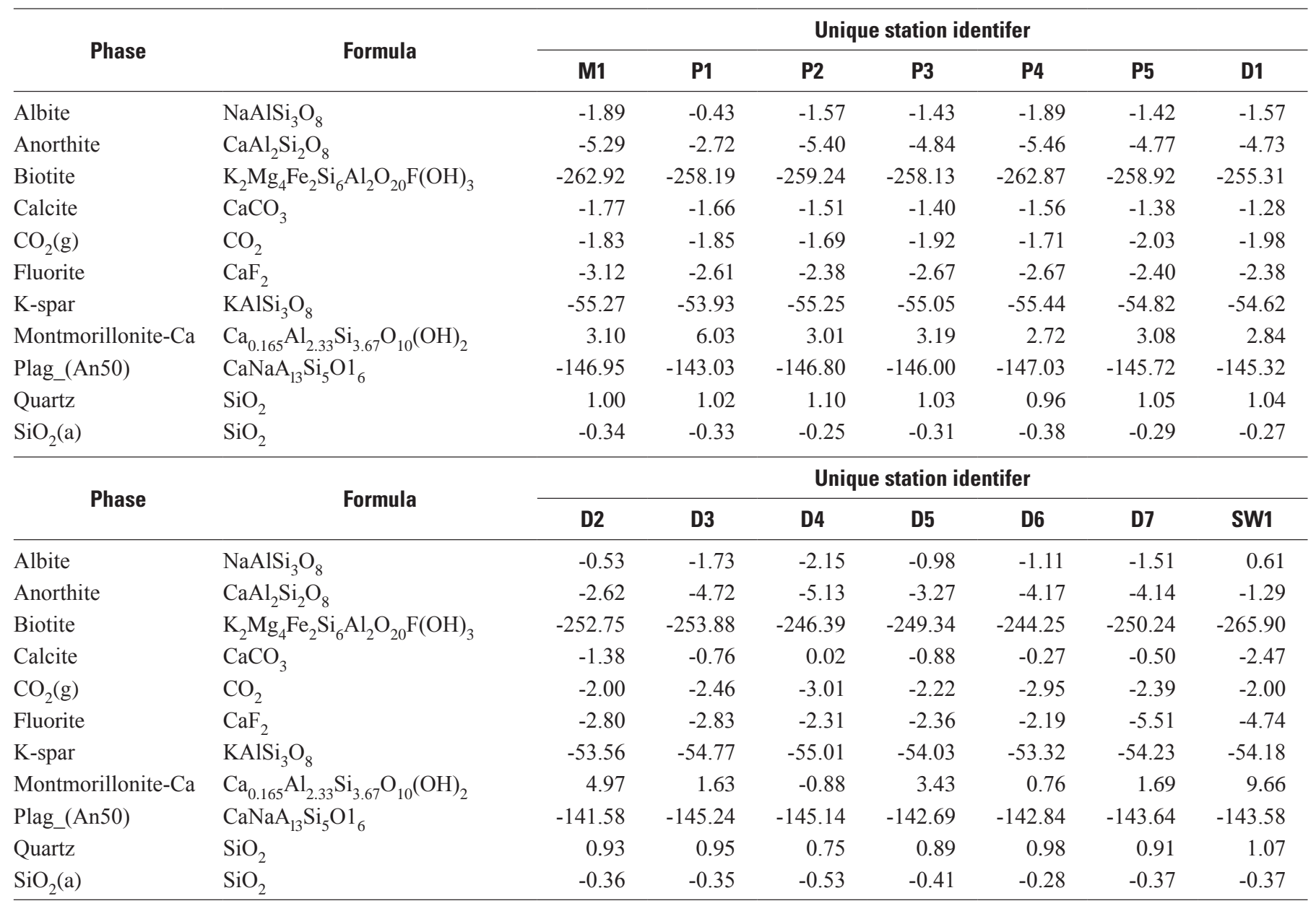


Table 11. Geochemical model simulations results using NETPATH, measured carbon-14 and calculated carbon-14 ages, and flow path modeling travel times for groundwater in the Mayfield area, southwestern Idaho, 2011-12.

[Wells listed by unique well identifier. Positive values indicate dissolution. Negative values indicate precipitation. Dilution and evaporation were not allowed. Modeled carbon-13 values matched observed carbon-13 values. Age calculated by NETPATH is the travel time between two modeled wells. "Modern" indicates water recharged since the 1950s. Plag-an45: plagioclase with 45 percent anorthite composition. Abbreviations $\mathrm{CO}_{2}$, carbon dioxide; pmc, percent modern carbon; $\mathrm{SiO}_{2}$, silicon dioxide]

\begin{tabular}{|c|c|c|c|c|c|c|c|c|c|c|c|c|c|c|}
\hline $\begin{array}{l}\text { Initial } \\
\text { well }\end{array}$ & $\begin{array}{l}\text { Final } \\
\text { well }\end{array}$ & $\mathrm{SiO}_{2}$ & Calcite & $\begin{array}{c}\text { Ferric } \\
\text { hydroxide }\end{array}$ & $\begin{array}{l}\text { Potassium } \\
\text { feldspar }\end{array}$ & Biotite & $\begin{array}{c}\text { Ca- } \\
\text { montmorillinite }\end{array}$ & $\begin{array}{l}\mathrm{CO}_{2} \\
\text { gas }\end{array}$ & Pyrite & Plag-an45 & Fluorite & $\begin{array}{c}\text { Measured } \\
\text { carbon-14 } \\
(p m c) \\
\text { final well }\end{array}$ & $\begin{array}{l}\text { Age at final } \\
\text { well from } \\
\text { carbon -13 } \\
\text { mixing model } \\
\text { (years) }\end{array}$ & $\begin{array}{c}\text { Calculated } \\
\text { travel time } \\
\text { NETPATH } \\
\text { (years) }\end{array}$ \\
\hline \multicolumn{15}{|c|}{ Mountain system to perched aquifer } \\
\hline M1 & P2 & -9.26190 & 0.36512 & -0.05005 & 6.50415 & 0.02825 & -3.08915 & 0.54810 & 0.00817 & 0.45884 & 0.00421 & 90.4 & 1,400 & Modern \\
\hline P3 & P4 & -1.90745 & 0.11104 & -0.02327 & 1.23607 & 0.00192 & -0.59040 & 0.26919 & 0.01999 & 0.09493 & 0.00027 & 111.3 & Modern & Modern \\
\hline \multicolumn{15}{|c|}{ Deep aquifer to deep aquifer } \\
\hline D3 & D5 & -5.89036 & 0.12706 & -0.08175 & 3.93132 & 0.03977 & -2.09806 & 0.04401 & 0.02296 & 0.63284 & 0.00343 & 55.3 & 6,700 & 1,222 \\
\hline D3 & D7 & -4.07992 & 0.15373 & -0.05053 & 2.78184 & 0.02414 & -1.46518 & 0.21932 & 0.01432 & 0.41929 & 0.00211 & 54.7 & 6,800 & 1,578 \\
\hline
\end{tabular}

Only five of the modeled flow paths produced model simulation results that matched the observed chemical concentrations in the water samples collected from the study (table 11); two of these five flow paths are shown in figure 7. Of the five flow paths, two flow paths produced successful models but need to be interpreted with caution; the two models generated in the deep aquifer (from D3 to D5 and D3 to D7) are not along realistic groundwater flow paths. Water from well D3 was used as a representative upgradient water source to these wells but is not along a realistic flow path. Calculated travel times between wells were estimated from carbon-14 and reactions with mineralogy (table 11). The corrected travel time, or the time it took for the water to travel between wells, ranged from 0 (modern) to 1,578 years. It should be noted that the travel time does not necessarily represent the age of the final water.

Mixing models provide an understanding of the possible sources of recharge to groundwater in the study area (table 12) by mixing a potential source of recharge into an existing flow path. Recharge water was represented by surface water (from the Indian Creek sample), or geothermal water (from Sacajawea Hot Spring or from Boise Geothermal water). Water from the perched aquifer also was allowed to act as an input water to mimic vertical leakage between the perched and deep aquifer. The Indian Creek sample seemed to be a valid input to all simulated flow paths from the mountain system to the perched aquifer and between wells in the perched aquifer; surface water contributed between 20 and 99 percent of water to the perched aquifer in these models. One simulated flow path successfully modeled Indian Creek mixing into a flow path within the deep aquifer. However, there were not any valid models that mixed Indian Creek along a flow path from the mountain system to the deep aquifer. It is important to note that mixing models with Indian Creek were not constrained by carbon- 13 values, so these models are presented with less confidence than other mixing models. Mixing models incorporating geothermal water allowed for the precipitation of calcite and fluorite due to changing temperature and saturation levels associated with cooling. Geothermal water mixed into flow paths from the mountain system to the deep aquifer did not produce any successful models. However, flow paths between wells within the deep aquifer were successfully modeled by mixing geothermal water; the final well appeared to receive between 1 and 23 percent of recharge from a geothermal source. Water from the perched aquifer did not successfully mix into any flow paths in the deep aquifer. Mixing models using surface water or geothermal water did not always produce valid models, suggesting that neither source solely accounts for recharge to groundwater. 
Table 12. Validity of mixing models using NETPATH, Mayfield area, southwestern Idaho, 2011-12.

[Wells listed by unique well identifier. Mixing success denotes ability of flow path to be modeled with input water. Abbreviaton: NA, not applicable]

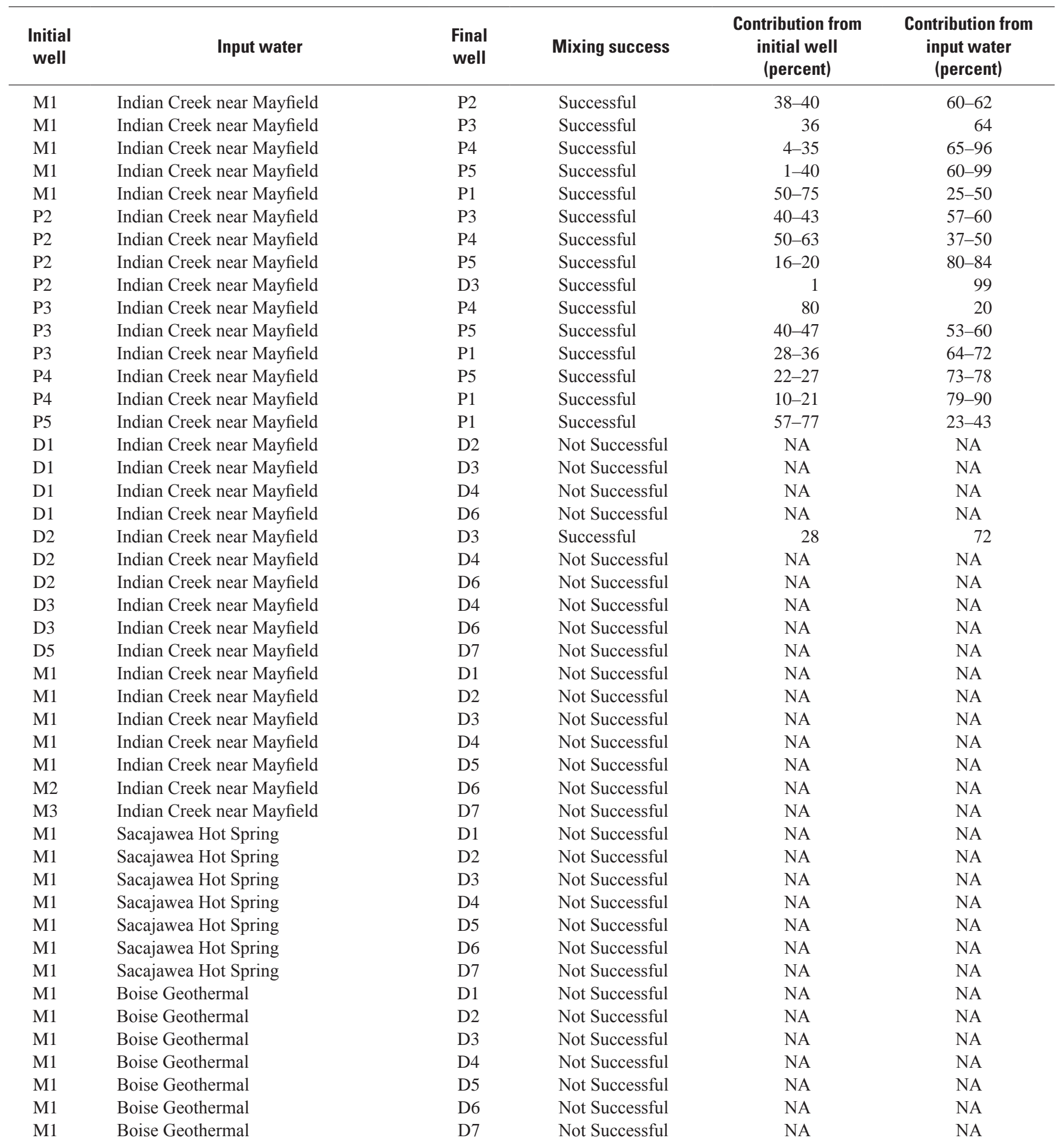


Table 12. Validity of mixing models using NETPATH, Mayfield area, southwestern Idaho, 2011-12.-Continued

[Wells listed by unique well identifier. Mixing success denotes ability of flow path to be modeled with input water. Abbreviation: NA, not applicable]

\begin{tabular}{|c|c|c|c|c|c|}
\hline $\begin{array}{c}\text { Initial } \\
\text { well }\end{array}$ & Input water & $\begin{array}{l}\text { Final } \\
\text { well }\end{array}$ & Mixing success & $\begin{array}{l}\text { Contribution from } \\
\text { initial well } \\
\text { (percent) }\end{array}$ & $\begin{array}{l}\text { Contribution from } \\
\text { input water } \\
\text { (percent) }\end{array}$ \\
\hline D1 & Sacajawea Hot Spring & D3 & Not Successful & NA & NA \\
\hline D1 & Sacajawea Hot Spring & D4 & Not Successful & NA & NA \\
\hline D1 & Sacajawea Hot Spring & D6 & Not Successful & NA & NA \\
\hline D1 & Boise Geothermal & D4 & Not Successful & NA & NA \\
\hline D1 & Boise Geothermal & D6 & Not Successful & NA & NA \\
\hline D2 & Sacajawea Hot Spring & D3 & Not Successful & NA & NA \\
\hline D2 & Sacajawea Hot Spring & D4 & Successful & $90-99$ & $1-10$ \\
\hline D2 & Sacajawea Hot Spring & D6 & Successful & 98 & 2 \\
\hline D3 & Sacajawea Hot Spring & D6 & Successful & $80-81$ & $19-20$ \\
\hline D5 & Sacajawea Hot Spring & D7 & Not Successful & NA & NA \\
\hline D3 & Boise Geothermal & D4 & Successful & 88-99 & $1-12$ \\
\hline D3 & Boise Geothermal & D6 & Successful & 77 & 23 \\
\hline D5 & Boise Geothermal & D7 & Not Successful & NA & NA \\
\hline D1 & P3 & D2 & Not Successful & NA & NA \\
\hline D1 & P3 & D3 & Not Successful & NA & NA \\
\hline D1 & P3 & D4 & Not Successful & NA & NA \\
\hline D1 & P3 & D6 & Not Successful & NA & NA \\
\hline D1 & $\mathrm{P} 4$ & D2 & Not Successful & NA & NA \\
\hline D1 & $\mathrm{P} 4$ & D3 & Not Successful & NA & NA \\
\hline D2 & P4 & D6 & Not Successful & NA & NA \\
\hline D3 & $\mathrm{P} 1$ & D4 & Not Successful & NA & NA \\
\hline D3 & $\mathrm{P} 1$ & D6 & Not Successful & NA & NA \\
\hline D4 & $\mathrm{P} 1$ & D6 & Not Successful & NA & NA \\
\hline D5 & $\mathrm{P} 1$ & D7 & Not Successful & NA & NA \\
\hline D3 & P5 & D4 & Not Successful & NA & NA \\
\hline D3 & P5 & D6 & Not Successful & NA & NA \\
\hline D4 & P5 & D6 & Not Successful & NA & NA \\
\hline D5 & P5 & D7 & Not Successful & NA & NA \\
\hline M1 & P5 & D1 & Not Successful & NA & NA \\
\hline M1 & $\mathrm{P} 1$ & D1 & Not Successful & NA & NA \\
\hline
\end{tabular}




\section{Geochemical Evidence for Recharge from Upwelling Geothermal Waters}

The chemistry of the water in some of the deep wells in the Mayfield area has similar characteristics to other geothermally influenced water in Idaho; previous reports (Welhan, 2012) hypothesized that geothermal water may contribute recharge to the area. Wood and Low's (1988) conceptual model of the western SRP suggests interaction between a deeper, geothermal aquifer consisting of interbedded rhyolite and volcanic sediments and an upper, cold-water aquifer composed of sediments and basalts of the Idaho and Snake River Groups. This model suggested that geothermal recharge in the western SRP is primarily sourced from precipitation falling on the flanks of the basin, which moves into the geothermal system, becomes heated, and slowly discharges to the cold-water aquifer through fractures. Welhan (2012) suggested that the same geothermal source that supplies the Boise Geothermal system and the hot springs of the Idaho Batholith may contribute significantly to the deep aquifer in the Mayfield area; chemistry can help to determine if a geothermal signature is present in groundwater in the deep aquifer. Wood and Low (1988) identified geothermal waters as having higher concentrations of sodium, bicarbonate, silica, fluoride, sulfate, chloride, arsenic, boron, and lithium and lower concentrations of calcium and magnesium than those in the cold-water aquifer. Water from some of the sampled wells in the deep aquifer in the Mayfield area exhibits some, but not all, of these chemical characteristics as compared to the perched aquifer; samples from the deep aquifer generally had higher concentrations of bicarbonate, arsenic, and lithium than those in the perched aquifer and they had lower concentrations of magnesium (figs. 3 and $\underline{5}$ ). Water type, as discussed above, in one deep aquifer samples (D6) is similar to that of Boise geothermal groundwater (sodium-bicarbonate type water) (Waag and Wood, 1987), suggesting a similarities between this well and geothermal groundwater.

The deep aquifer did not exhibit the high fluoride concentrations typical of Boise Geothermal water (deep aquifer, $0.19-0.51 \mathrm{mg} / \mathrm{L}$; Boise Geothermal water, 8 to $26 \mathrm{mg} / \mathrm{L}$ ) (Waag and Wood, 1987). Welhan hypothesized that fluorite solubility might control the fluoride concentrations in geothermal water and that extremely high fluoride concentrations in deep aquifer samples are not likely. Similarly, the deep aquifer water did not exhibit the high chloride concentrations typical of Idaho Batholith waters (deep aquifer, 2.3-7.6 mg/L; Boise geothermal water, $10-50 \mathrm{mg} / \mathrm{L}$ ) (Waag and Wood, 1987), suggesting that an Idaho Batholith geothermal water is not the predominant source of water to the comparatively dilute water found in the deep aquifer in the Mayfield area.
Water temperature had a positive correlation with depth, suggesting a geothermal component to water in the deep aquifer, but Welhan (2012) showed that water temperatures in the study area are only slightly higher than would be explained by the geothermal gradient for the region. A plot of $\mathrm{pH}$ and fluoride concentrations in samples (fig. 8) is capable of distinguishing water derived from a cold-water source from water influenced by a geothermal source (suggested by Waag and Wood, 1987). Samples from wells D4 and D6 plot separately from the perched aquifer samples in a plot of $\mathrm{pH}$ and fluoride, suggesting that the sources of water to these two wells is unique and that these two wells may be influenced by geothermal water (fig. 8).

A ternary diagram (fig. 9) with exaggerated lithium and boron concentrations was constructed to plot thermal waters from the Idaho Batholith (Berkeley Group, Inc., 1990; Parliman and Young, 1992; Druschel and Rosenberg, 2000) and water samples from the study area. Five samples collected from the deep aquifer plot close to thermal waters from the Idaho Batholith, suggesting geothermal water similar to that of the Idaho Batholith may recharge the deep aquifer. Only one sample from the perched aquifer plots near the Idaho Batholith thermal waters; this sample is the most upgradient sample in the perched aquifer and the closest to the mountain system. The surface-water sample plots near this signature, indicating that this sample was influenced by Idaho Batholith geology. All other perched aquifer samples plot far from the thermal water signature, suggesting these samples are not influenced by Idaho Batholith geology. Samples from wells D5 and D6 plot between the perched aquifer samples and the signature of the Idaho Batholith, indicating these samples carry the signature of both the perched and deep aquifers.

Welhan (2012) suggested that geothermal recharge in the Mayfield area originates from the same source as the Boise geothermal system, as evidenced by elevated fluoride, lithium, and boron concentrations. Geochemical mixing models confirmed that geothermal water may be added along a flow path between wells within the deep aquifer, suggesting that geothermal water may be recharging the aquifer in proportions consistent with those hypothesized by Welhan (2012). A variation in chemistry evident between two points in the deep aquifer (D3 and D4) suggests that geothermal water is introduced between points D3 and D4 (figs. 3, $\underline{5}$, and 7; table 2). Mixing models confirm that water from well D4 could contain geothermal water, implying that upwelling geothermal water may enter the study area to the northeast of Highway 84 . 

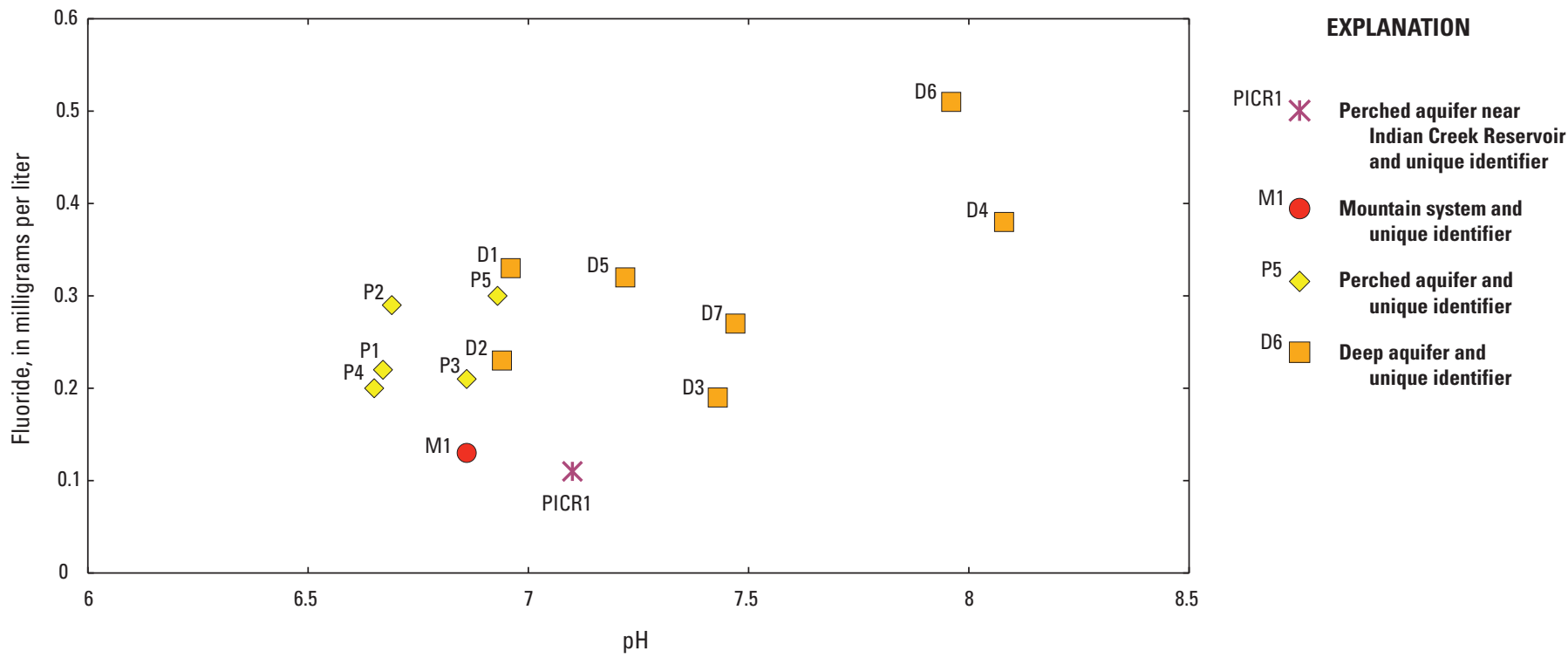

Figure 8. $\mathrm{pH}$ and fluoride concentrations in water samples collected from wells in Mayfield area, southwestern Idaho, 2011-12.

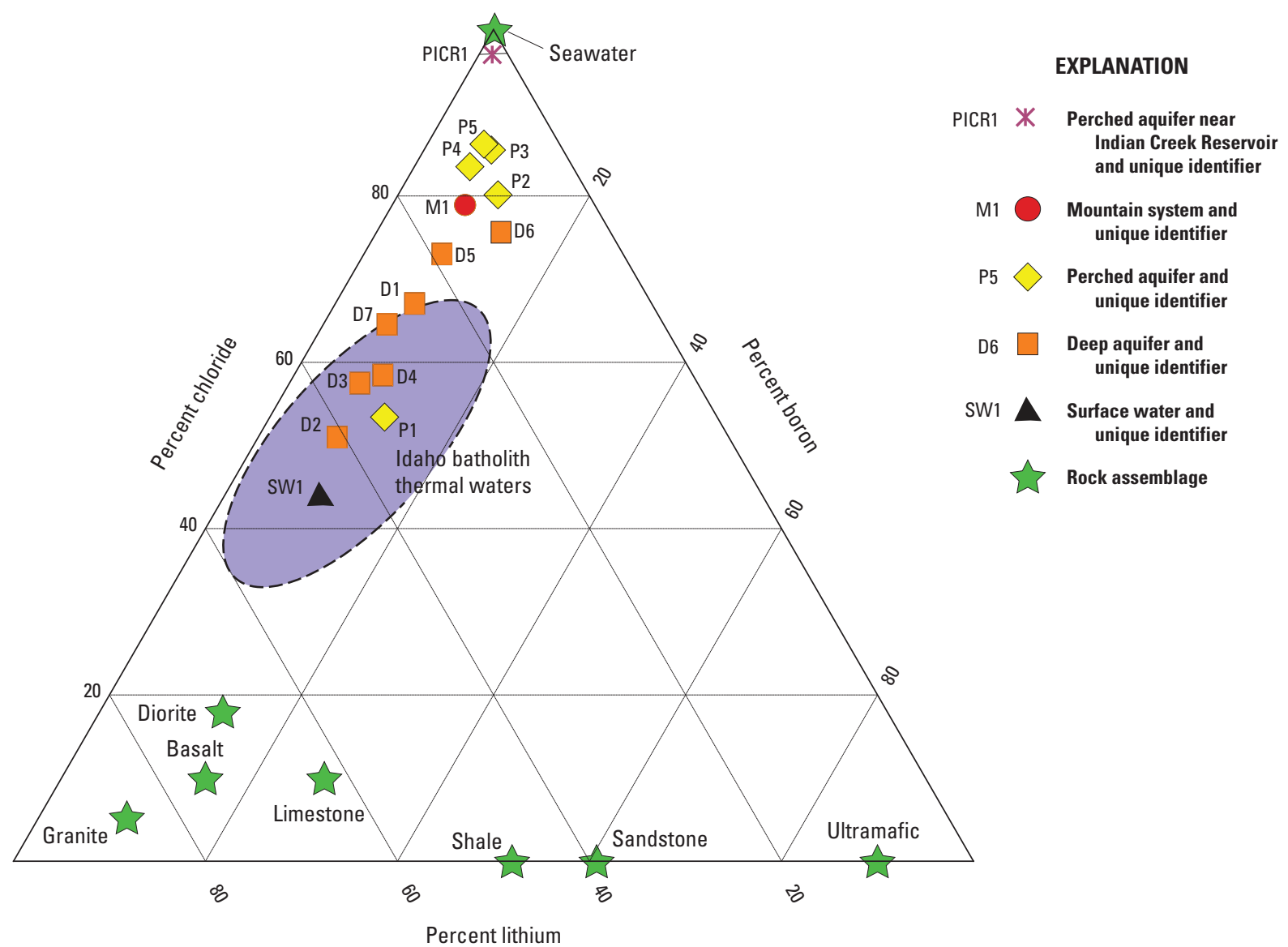

Figure 9. Water samples plotted with Idaho Batholith thermal water, Mayfield area, southwestern Idaho, 2011-12. For plotting purposes, boron concentrations were multiplied by 25 and lithium concentrations were multiplied by 100 . 


\section{Sources of Recharge as Suggested by Geochemical Tracers}

Concepts described in the Geochemical Evidence for Recharge from Upwelling Geothermal Waters section of this report suggest that various sources recharge groundwater in the study area. Identification of these sources of recharge can help to improve the current conceptual models of the study area and guide future decision making.

Oxygen-18 and deuterium signatures suggest that various sources of water exist in the study area (fig. 6). Water samples collected from the perched aquifer were more enriched (plot more positively) than samples from the deep aquifer; water from the mountain system had ratios that were similar to the perched aquifer, indicating a similar source of recharge. The more enriched signature seen in the perched aquifer could suggest that recharge occurred either at a lower altitude or during warmer precipitation events. The general climate and the hydrograph of Indian Creek (fig. 2) suggest that precipitation-sourced recharge is negligible during the summer because very little precipitation falls during warmer months. Therefore, the perched aquifer's isotopic signature suggests that recharge likely occurs as winter precipitation at low elevations (most likely on the alluvial fan). The more depleted $\delta^{18} \mathrm{O}$ values in the deep aquifer suggest a dominant source of recharge from a higher altitude such as the Danskin Mountains, or from recharge during colder months. The deep aquifer could also receive recharge from numerous sources and have an average signature of depleted $\delta^{18} \mathrm{O}$ values. Groundwater samples plot more positively than the winter runoff collected from Indian Creek, suggesting that either groundwater recharge occurs at a lower altitude than the upper Indian Creek drainage basin (represented by the surface water sample) or that precipitation is sourced from warmer weather events such as spring precipitation. All groundwater samples plot as more enriched than the mean geothermal water signature, but are still within a feasible range of geothermal values, suggesting that an upwelling geothermal water source could also influence stable isotopic values.

The percentage of young water in each sample (calculated by ratio dating with CFCs) plotted in cross section helps to confirm concepts of recharge (fig. 7). The mountain system well (M1) contains 20-52 percent young water, suggesting that fractures in the mountain system facilitate delivery of mountain precipitation to depth. The percentage of young water in P2, the next well downgradient, is much lower (between 1 and 6 percent), suggesting that although some modern water may recharge this well, a local confining unit may prevent recharge from precipitation and (or) young water from the mountain system. Samples downgradient show a larger percentage of young water, indicating that the perched aquifer receives modern recharge from precipitation and (or) surface-water infiltration. The deep aquifer shows an increasing percentage of young water downgradient, suggesting that young water may be recharging the deep aquifer by natural percolation, or from pumping activity that may induce mixing with younger, shallower water. Mixing models did not successfully model perched aquifer water mixing into flow paths between deep aquifer wells, suggesting that percolating precipitation or surface water provides modern recharge to the deep aquifer. This conclusion seems valid when paired with nutrient data; water samples from the deep aquifer contained CFCs but not high levels of nutrients, suggesting that the perched aquifer may receive more recharge from local application of high-nutrient water, whereas the deep aquifer receives low-nutrient recharge from a larger regional area.

Deviation in physical parameter, major ion, trace element, and nutrient data along a flow path in the perched aquifer and deep aquifer can identify areas experiencing recharge. Specific conductivities in sites D1, D2, and D3 are lower than those measured in the perched aquifer or farther downgradient in the deep aquifer (table 3); these sites most likely receive a component of recharge from precipitation or from dilute surface water that infiltrate through fractures and faults in the area. A change in the geochemical composition of deep groundwater is apparent between two wells (D3 and D4) (figs. 3 and $\underline{5}$ ) in the deep aquifer. Between these two points, sodium, fluoride and sulfate concentrations increase, whereas magnesium and arsenic concentrations decrease. These changes are likely attributed to the area receiving recharge from a geothermal source that contributes sodium, sulfur, and fluoride. Another obvious point of inflection on major ion plots is around D6; this well is located at the terminus of the flow path and far from other wells in this flow path. Hydrologic and geologic controls affecting water quality in the deep aquifer seem to be different at well D6 than in any of the other deep wells, possibly due to its distance from other wells in the study area.

Many lines of evidence indicate that there is an additional source of recharge for the deep aquifer than there is for the perched aquifer, such as an upwelling of geothermal water through fractures. The chemistry of the deep aquifer is somewhat similar to some geothermal water, suggesting that a component of the water in the deep aquifer is composed of geothermal water. Based on water temperatures, Welhan (2012) suggested that geothermal recharge to the Mayfield area may provide as much as 20 percent of the water to the deep aquifer composition. The simulation results of mixing models with geothermal end members suggest that geothermal water may comprise between 1 and 23 percent of the recharge to the deep aquifer. The composition of geothermal water that is actually present in the deep aquifer could be slightly different than the end members selected for the model; other processes, such as water-rock interaction, may be occurring in addition to mixing. The upwelling of older, warmer geothermal water explains the presence of older carbon-14 ages and warm temperatures that are in the deep aquifer. Recharge from the mountain system also could be contributing to deep aquifer wells; this end member would most likely carry a signature similar to the Idaho Batholith and would show evidence of water-rock interaction. 
The current conceptual model, taken from Welhan's (2012) study, suggests that both cold and warm-water sources account for recharge to aquifers in the Mayfield area. Evidence from data collected during this study confirms this concept. Precipitation recharges the aquifer through direct application and through ephemeral surface-water recharge. Mixing of multiple sources is evidenced by nutrient data, geochemical modeling, and the overlap of oxygen-18 and deuterium signatures in water from the perched and deep aquifers. Cold-water recharge moves vertically downward to the deep aquifer, bringing a modern source of recharge to the deep aquifer. The deep aquifer appears to receive recharge from the geothermal system as well, resulting in water with a geochemistry reflective of both modern, cold water and a geothermal component. Pumping may mix these various sources of water, either in the well or in the aquifer. Welhan (2012) also suggested that the proportions of recharge from these sources vary seasonally as a result of local pumping; local pumping could in fact induce surface-water recharge, mixing of water between aquifer components, or pull from a specific layer of an aquifer.

\section{Summary and Conclusions}

Fifteen water samples were collected from a network of 14 wells and 1 surface-water site in a relatively undeveloped area near Mayfield, Idaho. These samples were analyzed to determine the sources of recharge to the area aquifers, and the residence time of groundwater within distinct aquifers. Data and previously existing hydrologic information from the area were used in geochemical modeling and flow-path interpretations.

Distinct geochemical changes were observed along an assumed flow path, indicating areas of unique chemistry. A flow path in the perched aquifer showed variations in chemistry, suggesting that geochemical trends in the perched aquifer may be a product of depth or compartmentalization more than of distance in the flow path. Water in the deep aquifer may be diluted upgradient by recharge infiltration and influenced by another water source downgradient. A chemical variation was noted in concentrations between points D3 and D4; based on observed differences in the geochemical composition of waters in some of the deep aquifer wells, the upwelling of geothermal water is indicated to be occurring in between these wells.

Geochemical differences were noted between the perched and deep aquifers, suggesting that these aquifers are composed of different sources of recharge or are mixtures of various sources. Higher nutrient concentrations were detected in the perched aquifer, which also contained water with younger carbon-14 dates. These chemical signatures in the perched aquifer suggest a modern, anthropogenic source of high-nutrient water. Lower nutrient concentrations and a lower component of young water in the deep aquifer indicate that these two aquifers are somewhat distinct. Similarly, metals and trace element concentrations and oxygen-18 and deuterium signatures varied between the two aquifers, suggesting that these aquifers have different sources of water and different geochemical controls.

Recharge dates calculated by carbon-14 and chlorofluorocarbons (CFCs) varied. All groundwater samples contained detectable CFCs, indicating that they had at least a component of young recharge. Carbon-14 that was corrected using an open system carbon-13 mixing model indicated that water varied in age between 0 and 10,000 years. CFCs did not show a one-directional change along the deep-aquifer flow path. The presence of conflicting recharge dates suggests that recharge to the deep aquifer is a mixture of younger and older water.

Data from this study indicate modern recharge to aquifers in the Mayfield area is sourced from meteoric precipitation in and upgradient of the study area, infiltration of surface water from streams, and upwelling of geothermal water. Age tracers, elevated nutrient concentrations, and oxygen-18 signatures in water from the perched aquifer and mountain system suggest recharge to these systems is from winter precipitation and infiltration of ephemeral surface water. Young water in the deep aquifer is mostly likely recharged from high-elevation precipitation or surface water. However, it is apparent that another source of water having distinct geochemical characteristics is contributing recharge to the deep aquifer. The most likely source of this unique geochemical signature seen in the deep aquifer is the upwelling of geothermal water.

Water temperature data, geochemical results, and mixing models suggest that the deep aquifer may receive recharge from a geothermal source. Elevated concentrations of trace elements typical of geothermal water were detected in water from the deep aquifer; the major change in chemistry that may suggest upwelling geothermal water is seen between wells D3 and D4. Water in the deep aquifer generally carried a signature of geothermal water, suggesting at least a component of recharge to the deep aquifer comes from a geothermal source. Mixing models suggest that upwelling of geothermal water may contribute between 1 and 23 percent of recharge to the deep aquifer, similar to the proportion of geothermal water that Welhan (2012) hypothesized was recharging the deep aquifer.

Only five flow paths could be successfully modeled without mixing, indicating that the assumed flow path for this study may be incorrect or too simple. Variations in chemistry in the perched aquifer and differences in ages between samples suggest that the wells in the perched aquifer may not lie along a continuous flow path. At this time (2013), the role that faults and fractures play in facilitating groundwater flow is unknown. However, water samples collected from the most upgradient wells in the deep aquifer (D1, D2, and D3) suggest that dilute water is being transported to depth below the perched aquifer. The presence of CFCs in all samples indicates that some mechanism is allowing young water to enter the perched and deep aquifers and allowing recharge to occur. 


\section{Acknowledgments}

Thanks to the well owners who gave permission to sample their wells and especially for their time and assistance. The following individuals provided valuable technical information, discussion and suggestions during the preparation of this report: Jim Bartolino and Gordon Rattray of the USGS, John Welhan of Idaho Geological Survey, Sean Vincent of IDWR, and Craig Tesch of IDWR.

\section{References Cited}

Bendixsen, S., 1994, Summary of hydrologic conditions in the Mountain Home and Cinder Cone Butte areas: Boise, Idaho, Idaho Department of Water Resources, $17 \mathrm{p}$.

Berkeley Group, Inc., 1990, Boise geothermal aquifer studyFinal report: Boise, Idaho, Idaho Department of Water Resources, Contract No. DWR-89-03-46-102-54, 197 p.

Bureau of Reclamation, 2006, AgriMet-The Pacific Northwest cooperative agricultural weather networkAgriMet network map: Bureau of Reclamation, accessed Jan. 3, 2012, at http://www.usbr.gov/pn/agrimet/ agrimetmap/agrimap.html.

Church, J., 2007, Economic and population forecasts for Ada and Canyon Counties in Idaho (2007-2040): Boise, Idaho Economics, prepared for the Community Planning Association of Southwest Idaho (COMPASS), 87 p., accessed February 28, 2013, at http://www.compassidaho. org/documents/prodserv/demo/JohnChurchForecast.pdf.

Clark, I.D., and Fritz, Peter, 1997, Environmental isotopes in hydrogeology: New York, Lewis Publishers, 328 p.

Coplen, T.B., 1993, Uses of environmental isotopes, in Alley, W.M., ed., Regional ground-water quality: New York, Van Nostrand Reinhold, p. 227-254.

Coplen, T.B., 1996, New guidelines for reporting stable hydrogen, carbon, and oxygen isotope-ratio data: Geochemica et Cosmochimica Acta, v. 60, no. 17, p. 3,359-3,360.

Coplen, T.B., Wildman, J.D., and Chen, Julie, 1991, Improvements in the gaseous hydrogen-water equilibration technique for hydrogen isotope ratio analysis: Analytical Chemistry, v. 63, p. 910-912.

Craig, Harmon, 1961, Isotopic variations in meteoric waters: Science, v. 133 , no. 3,465, p. 1,702-1,703.

Druschel, K.D., and Rosenberg, P.E., 2000, Non-magmatic fracture-controlled hydrothermal systems in the Idaho Batholith — South Fork Payette geothermal system: Chemical Geology, v. 173, p. 271-291.
Fishman, M.J., ed., 1993, Methods of analysis by the U.S. Geological Survey National Water Quality LaboratoryDetermination of inorganic and organic constituents in water and fluvial sediments: U.S. Geological Survey Open-File Report 93-125, 217 p.

Fishman, M.J., and Friedman, L.C., eds., 1989, Methods for determination of inorganic substances in water and fluvial sediments: U.S. Geological Survey Techniques of Water-Resources Investigations, book 5, chap. A1, 545 p. (Also available at http://pubs.usgs.gov/twri/twri5-a1/.)

Godfrey, B. ,2000, Köppen climate classification for the conterminous United States: Moscow, Idaho, University of Idaho, accessed November 14, 2012, at: http://inside. uidaho.edu/appsOutput/metadataWAF/xml/Koppen $\underline{\text { ClimateClassificationfortheConterminousUnitedStates.xml. }}$

Hallberg, G.R., and Keeney, D.R., 1993, Nitrate, in Alley, W.M., ed., Regional ground-water quality: New York, Van Nostrand Reinhold, p. 297-322.

Hutchings, Jon, and Petrich, C.R., 2002, Ground water recharge and flow in the regional Treasure Valley aquifer system, geochemistry and isotope study: Boise, Idaho, Water Resources Research Institute, Research Report IWRRI-2002-08, 80 p.

Liberty, L.M., 2012, Geophysical characterization at the North Ada and East Ada sites-A 2012 Idaho Department of Water Resources report: Boise, Idaho, Boise State University, $32 \mathrm{p}$.

Mayo, A.L., Muller, A.B., and Mitchell, J.C., 1984, Geochemical and isotopic investigations of thermal water occurrences of the Boise front area, Ada County, Idaho: Boise, Idaho, Idaho Department of Water Resources Water Information Bulletin 30, Part 14, 55 p.

Mitchell, J., 1981, Geological, hydrological, geochemical, and geophysical investigations of the Nampa-Caldwell and adjacent areas, southwestern Idaho: Boise, Idaho, Idaho Department of Water Resources Water Resources Information Bulletin 30, Part 11, 143 p.

National Agricultural Statistics Service, 2011, CropScapeCropland data layer, 2010: National Agricultural Statistics Service, accessed February 19, 2013, at http://nassgeodata. gmu.edu/CropScape/.

Natural Resources Conservation Service, 2010, Idaho Snow Survey Program: National Resources Conservation Service Web site, accessed February 20, 2013, at http://www.id.nrcs. usda.gov/snow/. 
Neely, K.W., and Crockett, J.K., 1998, Ground water quality characterization and initial trend analyses for the Treasure Valley shallow and deep hydrogeologic subareas: Boise, Idaho, Idaho Department of Water Resources Water Information Bulletin 50, pt. 3, 76 p., 5 appendixes.

Newton, G.D., 1991, Geohydrology of the regional aquifer system, western Snake River Plain, southwestern Idaho: U.S. Geological Survey Professional Paper 1408-G, p. G1-G52, 1 pl.

Norton, M.A., Ondrechen, William, and Baggs, J.L., 1982, Groundwater investigation of the Mountain Home plateau, Idaho: Boise, Idaho, Idaho Department of Water Resources Open-File Report, 62 p.

O'Neil, J.M., and Lopez, D.A., 1985, Character and regional significance of Great Falls tectonic zone, east-central Idaho and west-central Montana: American Association of Petroleum Geologists Bulletin, v. 69, no. 3, p. 436-447.

Parliman, D.J., and Young, H.W., 1992, Compilation of selected data for thermal-water wells and springs in Idaho, 1921 through 1991: U.S. Geological Survey Open-File Report 92-175, 201 p. (Also available at http://pubs.er.usgs. gov/publication/ofr92175.)

Pearson, F.J., Jr., and White, D.E., 1967, Carbon-14 ages and flow rates of water in the Carrizo Sand, Atascosa County, Texas: Water Resources Research, v. 3, no. 1, p. 251-261.

Peel, M.C., Finlayson, B.L., and McMahon, T.A., 2007, Updated world map of the Köppen-Geiger climate classification: Hydrology and Earth System Sciences, v. 11, p. 1,633-1,644, accessed February 20, 2013, at http://www. hydrol-earth-syst-sci.net/11/1633/2007/hess-11-1633-2007. pdf.

Phillips, W.M., Lewis, R.S., Gillerman, V.S., Garwood, D.L., and Stewart, D.E., 2012, Geologic map of the Mayfield area, Ada and Elmore Counties, Idaho: Idaho Geological Survey Digital Web Map DWM-144, scale 1:36,000.

Plummer, L.N., Michel, R.L., Thurman, E.M., and Glynn, P.D., 1993, Environmental tracers for age-dating young ground water, in Alley, W.M., ed., Regional ground-water quality: New York, Van Nostrand Reinhold, p. 255-294.

Plummer, L.N., Prestemon, E.C., and Parkhurst, D.L., 1994, An interactive code (NETPATH) for modeling net geochemical reactions along a flow path version 2.0: U.S. Geological Survey Water-Resources Investigations Report 94-4169.
Révész, Kinga, and Coplen, T.B., 2008a, Determination of the $\delta\left({ }^{18} \mathrm{O} /{ }^{16} \mathrm{O}\right)$ of water-RSIL lab code 489 , chap. $\mathrm{C} 2$ of Révész, Kinga, and Coplen, T.B., eds., Methods of the Reston Stable Isotope Laboratory: U.S. Geological Survey Techniques and Methods 10-C2, 28 p. (Also available at http://pubs.usgs.gov/tm/2007/tm10c2/.)

Révész, Kinga, and Coplen, T.B., 2008b, Determination of the $\delta\left({ }^{2} \mathrm{H} /{ }^{1} \mathrm{H}\right)$ of water-RSIL lab code 1574 , chap. $\mathrm{C} 1$ of Révész, Kinga, and Coplen, T.B., eds., Methods of the Reston Stable Isotope Laboratory: U.S. Geological Survey Techniques and Methods 10-C1, $27 \mathrm{p}$. (Also available at http://pubs.usgs.gov/tm/2007/tm10c1/.)

Schlegel, M.E., Mayo, A.L, Nelson, Steve, Tingey, Dave, Henderson, Rachel, and Eggett, Dennis, 2009, Paleoclimate of the Boise area, Idaho from the last glacial maximum to the present based on groundwater $\delta^{2} \mathrm{H}$ and $\delta^{18} \mathrm{O}$ compositions: Quaternary Research, v. 71, no. 2, p. $172-180$.

Shervais, J.W., Shroff, G., Vetter, S.K., Matthews, S. Hanan, B.B., and McGee, J.J., 2002, Origin and evolution of the western Snake River Plain-Implications from stratigraphy, faulting, and the geochemistry of basalts near Mountain Home, Idaho: Idaho Geological Survey Bulletin 30, p. 343-361, accessed December 5, 2012, at http://www.usu. edu/geo/shervais/Shervais_ElectronicPubList.htm.

SPF Water Engineering, 2007a, Ground-water supply evaluation for the Mayfield townsite property: SPF Water Engineering, 30 p., plus appendixes.

SPF Water Engineering, 2007b, Groundwater supply evaluation for Elk Creek Village, Application for Permit No. 61-12090: SPF Water Engineering, 17 p., plus appendixes.

U.S. Department of Agriculture, 2012, Common land use GIS database: Salt Lake City, Utah, U.S. Department of Agriculture-FSA Aerial Photography Office, series number 20051107.

U.S. Geological Survey, variously dated, National field manual for the collection of water-quality data: U.S. Geological Survey Techniques of Water-Resources Investigations, book 9, chaps. A1-A9. (Also available at http://pubs.water. usgs.gov/twri9A.)

U.S. Geological Survey, 2006, The Reston Chlorofluorocarbon Laboratory_-Dissolved gas $\mathrm{N}_{2} / \mathrm{Ar}$ and ${ }^{4} \mathrm{He}$ sampling instructions: U.S. Geological Survey Web site, accessed February 20, 2013, at http://water.usgs.gov/lab/dissolvedgas/sampling/.

U.S. Geological Survey, 2009, The Reston Chlorofluorocarbon Laboratory-CFC bottle sampling method: U.S. Geological Survey Web site, accessed February 20, 2103, at http:// water.usgs.gov/lab/chlorofluorocarbons/sampling/bottles/. 
U.S. Geological Survey, 2011, National Water Information System (NWISWeb) - USGS water-quality data for Idaho: U.S. Geological Survey database, accessed February 20, 2013, at http://waterdata.usgs.gov/id/nwis/qw.

U.S. Geological Survey, 2012a, The Reston Chlorofluorocarbon Laboratory-Analytical procedures for CFCs: U.S. Geological Survey Web site, accessed February 20, 2013, at http://water.usgs.gov/lab/ chlorofluorocarbons/lab/analytical procedures/.

U.S. Geological Survey, 2012b, The Reston Chlorofluorocarbon Laboratory-Analytical procedures for CFCs: U.S. Geological Survey Web site, accessed July 17, 2012, at http://water.usgs.gov/lab/chlorofluorocarbons/lab/ analytical procedures/.

Waag, C.J., and Wood, S.H., 1987, Evaluation of the Boise Geothermal System: Boise, Idaho, Boise State University, Department of Geology and Geophysics, Final report to Idaho Department of Water Resources, 168 p.

Welhan, J.A., 2012, Preliminary hydrogeologic analysis of the Mayfield area, Ada and Elmore Counties, Idaho: Idaho Geological Survey, 42 p.

Western Regional Climate Center, 2008, Idaho climate summaries: Western Regional Climate Center, accessed February 20, 2013, at http://www.wrcc.dri.edu/summary/ climsmid.html.

Whitehead, R.L., 1986, Geohydrologic framework of the Snake River Plain, Idaho and eastern Oregon: U.S. Geological Survey Hydrologic Investigations Atlas HA-681, 3 sheets, scale 1:1,000,000.
Williams, M.L., and Etheridge, A.B., 2013, An evaluation of seepage gains and losses in Indian Creek Reservoir, Ada County, Idaho, April 2010-November 2011: U.S. Geological Survey Scientific Investigations Report 2013-5047, 26 p.

Wood, S.H., 1994, Seismic expression and geological significance of a lacustrine delta in Neogene deposits of the western Snake River Plain, Idaho: American Association of Petroleum Geologists Bulletin, v. 78, p. 102-121.

Wood, S.H., and Anderson, J.E., 1981, Geology, in Mitchell, J.C., ed., Geothermal investigations in Idaho, part 11, Geological, hydrological, geochemical, and geophysical investigations of the Nampa-Caldwell and adjacent areas, southwestern Idaho: Boise, Idaho, Idaho Department of Water Resources Water Information Bulletin 30, p. 9-31.

Wood, S.H., and Clemens, D.M., 2002, Geologic and tectonic history of the western Snake River Plain, Idaho and Oregon, in Bonnichsen, Bill, White, C.M., and McCurry, Michael, eds., Tectonic and magmatic evolution of the Snake River Plain volcanic province: Moscow, Idaho, Idaho Geological Survey Bulletin 30, p. 69-103.

Wood, W.W., and Low, W.H., 1988, Solute geochemistry of the Snake River Plain Regional Aquifer system, Idaho and eastern Oregon: U.S. Geological Survey Professional Paper, 1408-D, 79 p.

Woods Hole Oceanographic Institution, 2003, Measuring ${ }^{14} \mathrm{C}$ in seawater $\Sigma \mathrm{CO} 2$ by accelerator mass spectrometry: Woods Hole, Mass., WHP Operations and Methods, 9 p. 
Publishing support provided by the U.S. Geological Survey Publishing Network, Tacoma Publishing Service Center

For more information concerning the research in this report, contact the Director, Idaho Water Science Center

U.S. Geological Survey

230 Collins Road

Boise, Idaho 83702

http://id.water.usgs.gov

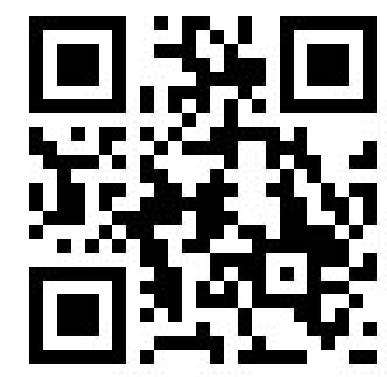


